B O N N E V I L L E Chief Joseph Kokanee Enhancement Project

Characterization of Pump Flow at the Grand Coulee Dam Pumping Station for Fish Passage

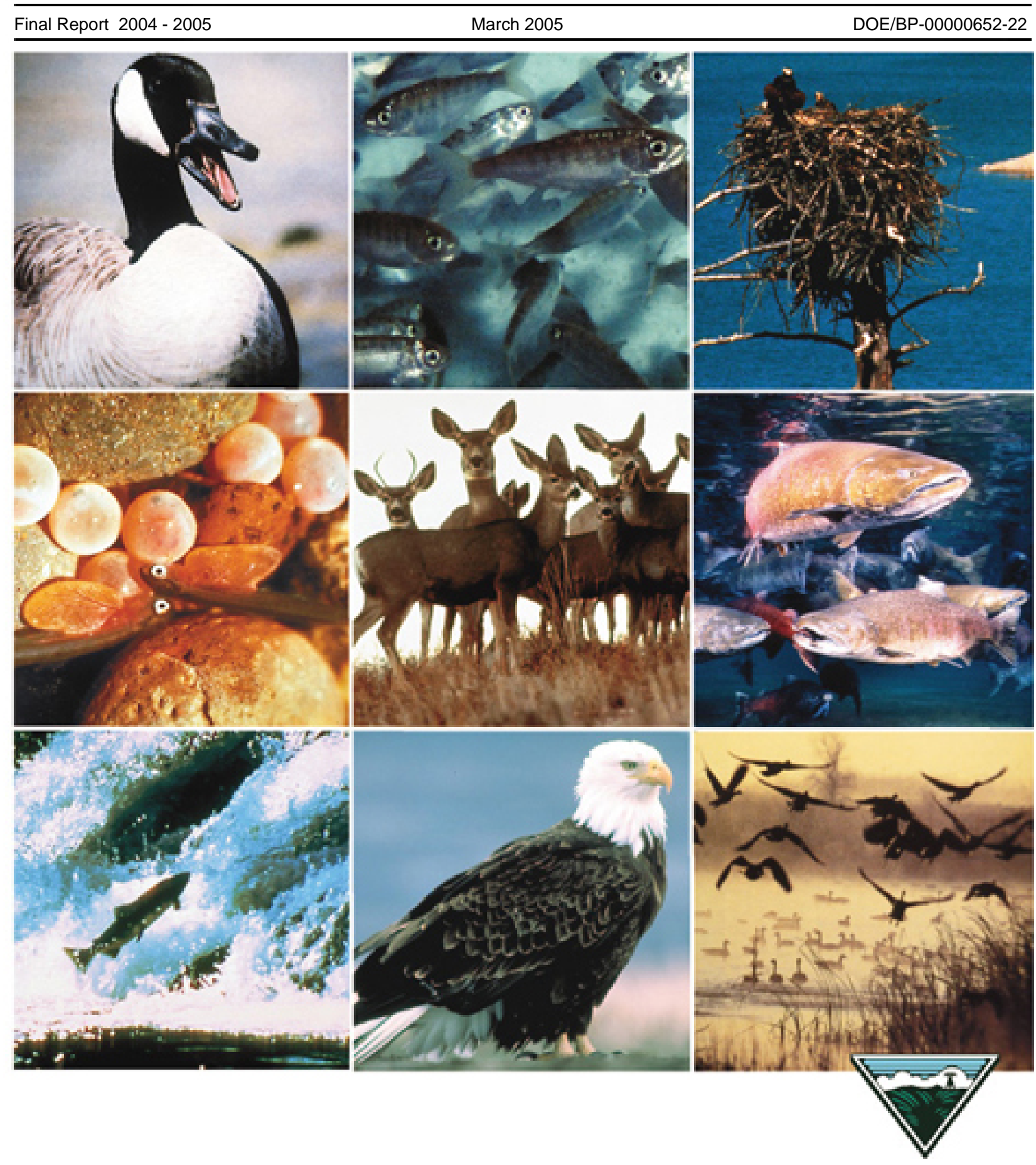


This Document should be cited as follows:

Carlson, T., J. Duncan, R. Johnson, "Chief Joseph Kokanee Enhancement Project;

Characterization of Pump Flow at the Grand Coulee Dam Pumping Station for Fish Passage",

2004-2005 Final Report, Project No. 199501100 (et al.), 40 electronic pages, (BPA Report

DOE/BP-00000652-22)

Bonneville Power Administration

P.O. Box 3621

Portland, OR 97208

This report was funded by the Bonneville Power Administration (BPA), U.S. Department of Energy, as part of BPA's program to protect, mitigate, and enhance fish and wildlife affected by the development and operation of hydroelectric facilities on the Columbia River and its tributaries. The views in this report are the author's and do not necessarily represent the views of BPA. 


\section{Characterization of Pump Flow at the Grand Coulee Dam Pumping Station for Fish Passage, 2004}

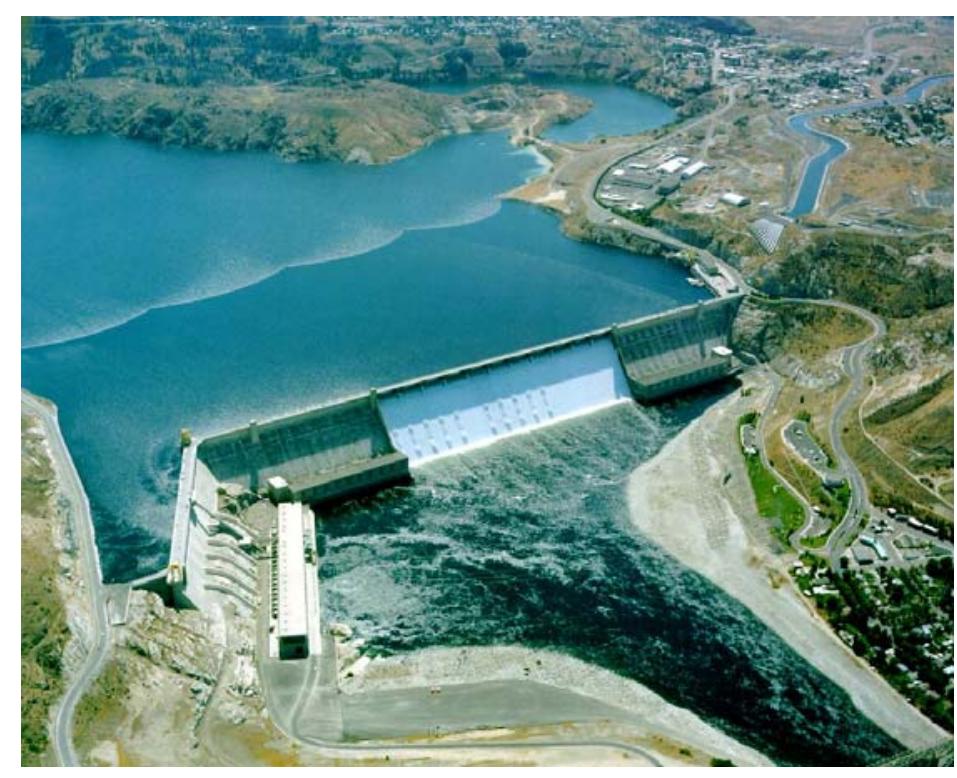

TJ Carlson

JP Duncan

RL Johnson

FINAL REPORT

March 31, 2005

Prepared for the Bonneville Power Administration under a Related Services Agreement with the U.S. Department of Energy

Contract DE-AC05-76RL01830

\section{Pacific Northwest National Laboratory}




\title{
DISCLAIMER
}

This report was prepared as an account of work sponsored by an agency of the United States Government. Neither the United States Government nor any agency thereof, nor Battelle Memorial Institute, nor any of their employees, makes any warranty, express or implied, or assumes any legal liability or responsibility for the accuracy, completeness, or usefulness of any information, apparatus, product, or process disclosed, or represents that its use would not infringe privately owned rights. Reference herein to any specific commercial product, process, or service by trade name, trademark, manufacturer, or otherwise does not necessarily constitute or imply its endorsement, recommendation, or favoring by the United States Government or any agency thereof, or Battelle Memorial Institute. The views and opinions of authors expressed herein do not necessarily state or reflect those of the United States Government or any agency thereof.

\author{
PACIFIC NORTHWEST NATIONAL LABORATORY \\ operated by \\ BATTELLE \\ for the \\ UNITED STATES DEPARTMENT OF ENERGY \\ under Contract DE-AC05-76RL01830
}

Printed in the United States of America
Available to DOE and DOE contractors from the
Office of Scientific and Technical Information,
P.O. Box 62, Oak Ridge, TN 37831-0062;
ph: (865) 576-8401
fax: (865) 576-5728
email: reports@adonis.osti.gov

Available to the public from the National Technical Information Service,

U.S. Department of Commerce, 5285 Port Royal Rd., Springfield, VA 22161

ph: (800) $553-6847$

fax: (703) 605-6900

email: orders@ntis.fedworld.gov

online ordering: http://www.ntis.gov/ordering.htm

This document was printed on recycled paper. 


\section{Characterization of Pump Flow at the Grand Coulee Dam Pumping Station for Fish Passage, 2004}

TJ Carlson

JP Duncan

RL Johnson

FINAL REPORT

March 31, 2005

Prepared for the Bonneville Power Administration under a Related Services Agreement with the U.S. Department of Energy Under Contract DE-AC05-76RL01830

Pacific Northwest National Laboratory

P.O. Box 999

Richland, Washington 99352 



\section{Summary}

This report describes a study conducted by Pacific Northwest National Laboratory (PNNL) for the Bonneville Power Administration to characterize the conditions fish experience when entrained in pump flow at the Grand Coulee Dam. PNNL conducted field studies at Grand Coulee Dam in 2004 using the Sensor Fish to measure the acceleration and pressure conditions that might be experienced by fish that pass through pumps at Grand Coulee Dam's Pump-Generating Plant and are transported up into the feeder canal leading to Banks Lake. The probability that fish would be struck by the Pump-Generating Plant's new nine-bladed turbines was also estimated.

Our measurements showed relatively low turbulence except in the immediate vicinity of the runner environment. The lowest and highest pressures experienced by the Sensor Fish were 6.4 and 155 psi (the pressure gauge saturated at $155 \mathrm{psi}$ ). The probability of strike was also calculated, based on the average length of hatchery-reared juvenile kokanee (land-locked sockeye). Strike probabilities ranged from 0.0755 for 2.36 -inch fish to 0.3890 for 11 .8-inch fish. The probability of strike estimates indicate that the majority (77\%) of recently released hatchery kokanee would be carried through the test pump without being struck and most likely with low risk of injury resulting from pressure and turbulence exposure. Of the $23 \%$ that might be struck it is expected that $60 \%$ would arrive in Banks Lake without visible external injuries. Thus more than $90 \%$ of entrained fish could be expected to arrive in Banks Lake without significant injury, assuming that no kokanee were injured or killed by pressure exposure during passage. 
Characterization of Pump Flow at the Grand Coulee Dam Pumping Station for Fish Passage, 2004 


\section{Acknowledgments}

Our study would not have been possible without the assistance of staff and equipment provided by the Colville Confederated Tribes. Richard LeCaire, lead for the Chief Joseph Kokanee Enhancement Program, and Steve Francis helped with the release and recovery of Sensor Fish and many other aspects of planning and execution of the study.

We wish to thank the Bonneville Power Administration for their sponsorship of this work through the Colville Confederated Tribes' Chief Joseph Kokanee Enhancement Program. We thank Steve Sauer and Jan Schrader from the Bureau of Reclamation for their assistance in understanding the pump environment and planning the sensor release location. Our work would not have been possible without the assistance of the operation and maintenance crews at Grand Coulee, who among other things removed access hatches permitting us access to the turbine pump intake. We also acknowledge the support provided by the U.S. Department of Energy Wind and Hydropower Technologies Program for development of the Sensor Fish Device and for providing the sensors used for the study.

We also acknowledge the assistance of Pacific Northwest National Laboratory staff Dan Tano and Ian Welch who assisted with equipment setup. Ian was also responsible for radio tracking during recovery of the Sensor Fish in Banks Lake. 
Characterization of Pump Flow at the Grand Coulee Dam Pumping Station for Fish Passage, 2004 


\section{Contents}

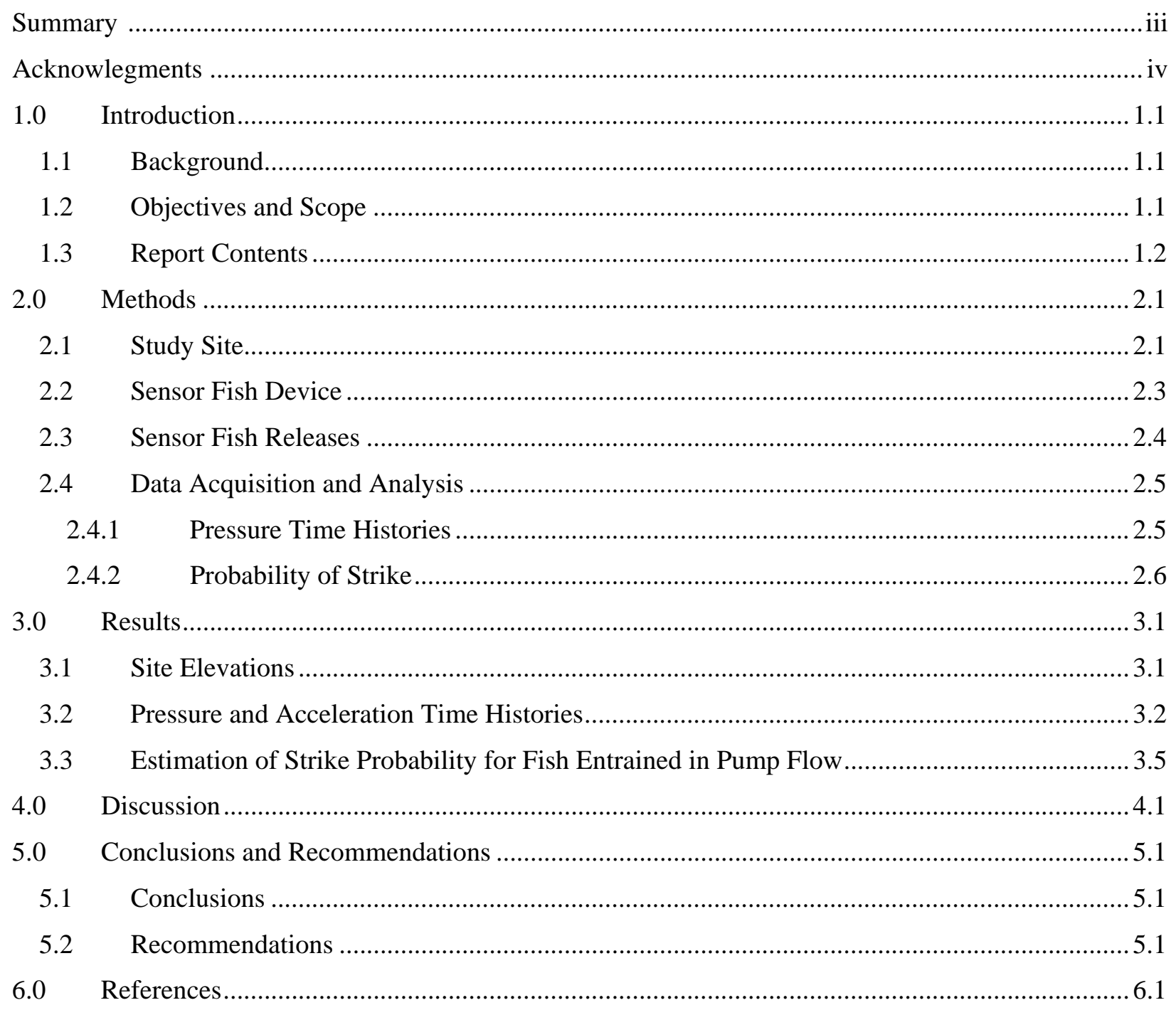


Characterization of Pump Flow at the Grand Coulee Dam Pumping Station for Fish Passage, 2004 


\section{Figures}

Figure 2.1. Grand Coulee Dam, Washington................................................................................... 2.1

Figure 2.2. Canal carrying water from Lake Roosevelt through the pump-generating units to Banks Lake.

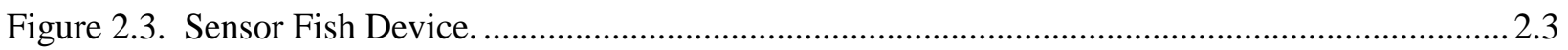

Figure 2.4. Apparatus used for deployment of Sensor Fish Devices into pump unit \#5.......................... 2.5

Figure 3.1. Cross-section through the centerline of pump unit \#6 at the Grand Coulee Pump-Generation Plant

Figure 3.2. Example gage pressure time history for a Sensor Fish passage through pump unit \#5.......... 3.2

Figure 3.3. Gage pressure and acceleration magnitude time histories for passage of Sensor Fish release F217_4 through pump unit \#5, the pump discharge pipe, and entry into the Banks Lake feeder canal.

Figure 3.4. Gage pressure and acceleration magnitude time histories for passage of Sensor Fish release F264_3 through pump unit \#5, the pump discharge pipe, and entry into the Banks Lake feeder canal.

Figure 3.5. Gage pressure and acceleration magnitude time histories for passage of Sensor Fish release F264_2 through pump unit \#5, the pump discharge pipe, and entry into the Banks Lake feeder canal.

Figure 3.6. A portion of a Sensor Fish's gage pressure and acceleration magnitude time histories during passage through pump unit \#5.

Figure 3.7. Photograph of an original seven-vane design pump runner for pump units 1-6 at the Grand Coulee Pump-Generation station

Figure 3.8. Measuring the height of the discharge leading edge of the pump runner vane.

Figure 3.9. View looking into the intake of the pump runner showing the openings of the runner vanes.

Figure 3.10. Measuring the width of the opening of the pump intake vanes .......................................... 3.8

Figure 3.11. Installation of a Francis runner at the Third Powerhouse at Grand Coulee Dam.

Figure 3.12. Plot of the estimates of strike probability as a function of fish size for passage through the seven-vane pump runner of pump unit \#5 at the Grand Coulee Pump-Generation Plant.....

Figure 4.1. One of the original Kaplan turbine runners installed in the later 1930s at the Bonneville Dam first powerhouse.

Figure 4.2. Spill discharge for fish passage at Bonneville Dam. 


\section{Tables}

Table 3.1. Estimates of various passage exposure metrics abstracted from pressure and acceleration magnitude time histories recovered from successful Sensor Fish releases through pump unit \#5 at the Grand Coulee Pump-Generation Plant.

Table 3.2. Estimates of rate of change in pressure and water velocity for the high-slope section of the pump \#5 discharge pipe.

Table 3.3. Measurements of physical features of an original seven-bladed pump runner identical to that in test pump unit \#5.

Table 3.4. Estimates of strike probability as a function of fish size for passage through the seven-vane pump runner of pump unit \#5 at the Grand Coulee Pump-Generation Plant.... 


\subsection{Introduction}

This report describes a study conducted by Pacific Northwest National Laboratory (PNNL) in conjunction with the Confederated Tribes of the Colville Reservation (Colville Confederated Tribes) for the Bonneville Power Administration, U.S. Department of Energy, to characterize the conditions fish experience when entrained in pump flow at the Grand Coulee Dam on the Columbia River in northeastern Washington State. PNNL used the Sensor Fish to measure the acceleration and pressure conditions that might be experienced by fish during passage through pumps at Grand Coulee Dam's Pump-Generating Plant and transported up into the feeder canal leading to Banks Lake. Sensor Fish releases were made during field tests at the dam over a two-day period in September 2004. The probability that fish would be struck during passage through one of the original design pumps at the Pump-Generating Plant was also estimated using Monte Carlo simulation.

\subsection{Background}

The construction of Grand Coulee and Chief Joseph dams on the Columbia River in 1933 and 1956, respectively, resulted in the complete extirpation of the anadromous fishery upstream of these structures. Today, the area above the two dams is totally dependent upon resident fish resources to support local fisheries. Target species in the existing fishery include, but are not limited to, kokanee salmon, rainbow trout, white sturgeon (Acipenser transmontanus), and walleye (Sander vitreum). Kokanee, a land-locked sockeye salmon, is a species of special interest because of its historical significance to native cultures and its role in the functioning ecosystem within the affected area.

Pen-reared kokanee are released into Lake Roosevelt. The intent of this activity is to initiate a selfsustaining population of fish to serve as the base for a recreational fishery in Lake Roosevelt. It has been known for some time that an unknown proportion of these fish are transported into Banks Lake in water pumped from Lake Roosevelt via the Grand Coulee Pump-Generating Plant. In turn, an unknown portion of these fish are known to survive the trip since they are found in the Banks Lake sport fishery managed by Washington State.

\subsection{Objectives and Scope}

The objective of the task described in this report was to characterize the conditions fish experience when entrained in pump-back flow and carried into the Banks Lake feeder canal from the forebay of Grand Coulee Dam.

PNNL has been conducting tests of a strobe light system to deter fish from entering the third powerplant forebay since 2002. During the course of this study, we have discovered that some of the fish that were tagged with acoustic transmitters traveled across the channel and were found in proximity to the Pump-Generating Plant. Biologists of the Colville Confederated Tribes are concerned that mitigation fish produced for the benefit of the tribes in Lake Roosevelt may be lost to the fishery through the PumpGenerating Plant operation and end up in non-tribal waters, namely Banks Lake. This study was appended to the strobe light study to evaluate the conditions fish would encounter if entrained in 
pumpback flow and to consider if fish pumped into Banks Lake would likely survive and potentially contribute to that fishery.

\subsection{Report Contents}

Chapter 2 describes the study site at Grand Coulee Dam, the Sensor Fish, methods used to deploy Sensor Fish, and the methodology for calculating strike probability. Chapter 3 provides results of our field study at Grand Coulee Dam and results of strike probability calculations. Chapter 4 is a discussion of results. Chapter 5 is conclusions and recommendations. 


\subsection{Methods}

\subsection{Study Site}

Grand Coulee Dam (Figure 2.1), located on the mainstem of the Columbia River approximately 90 miles west of Spokane, Washington, is the first dam encountered on the Columbia after the river enters the United States from Canada. Owned and operated by the U.S. Bureau of Reclamation, Grand Coulee Dam is over 5,000 feet long and 550 feet tall. The project contains four power plants (a Pump-Generating Plant and the left, right, and third power plants) and an 11-bay spillway. Construction of the main dam complex (left and right power plants and spillway) began in December 1933 and was completed in 1942. Construction of the pumping plant was initiated in 1946 and completed in 1951 . Between 1967 and 1974, the dam was modified with the addition of the third powerhouse, which was added to increase generating capacity. In 1983, four additional pump/generators were added to the pumping plant, which originally had pumps only. The 33 generators at Grand Coulee have a total generating capacity of 6,809 MW.

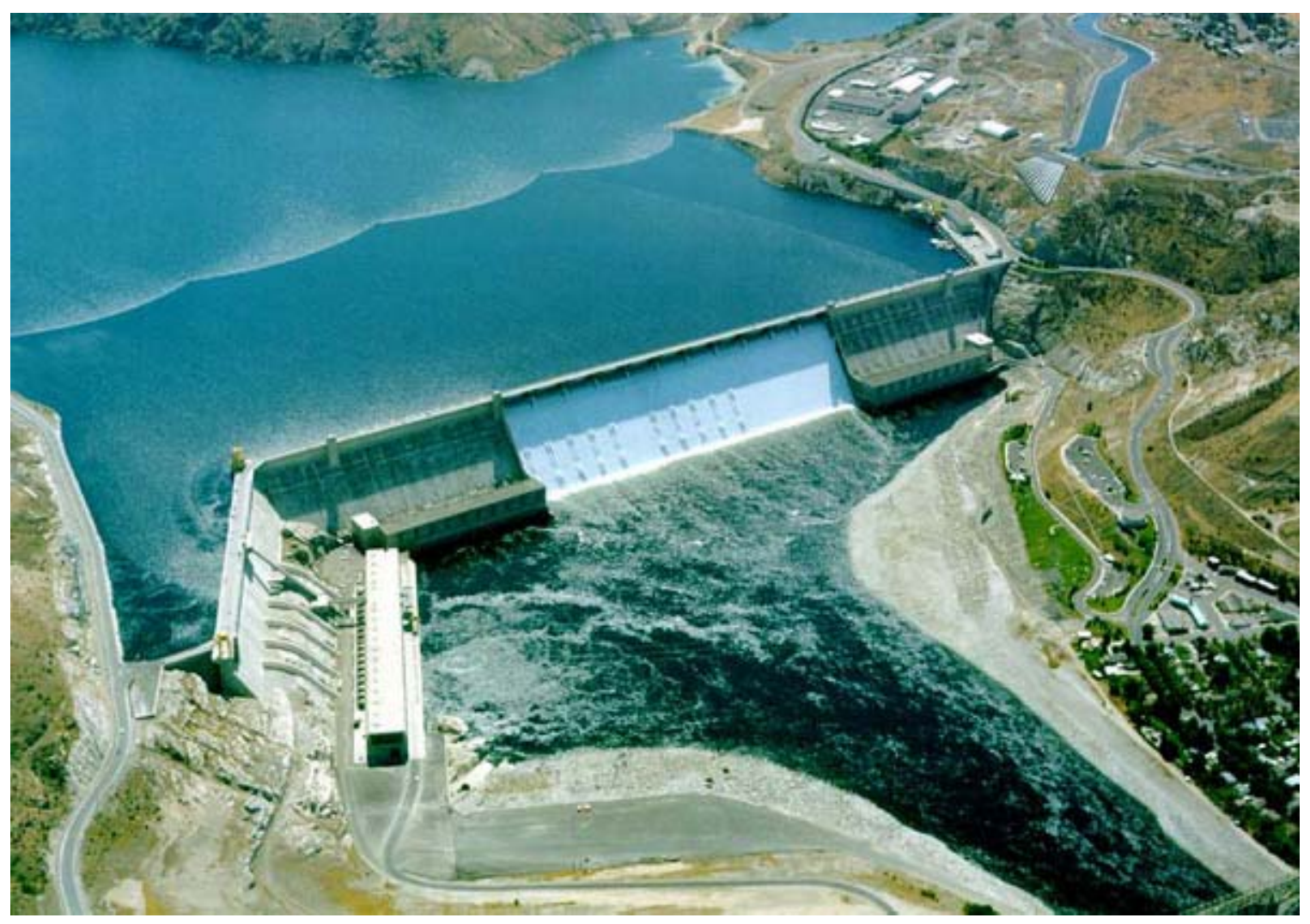

Figure 2.1. Grand Coulee Dam, Washington. The Pump-Generation Plant is shown in the upper right of the photo just above the left powerhouse. 
Lake Roosevelt, the reservoir created by the dam, extends about 150 miles northeast to the Canadian border. The total storage capacity of Lake Roosevelt is approximately 9.5 million acre-feet.

After initial construction, the Pump-Generating Plant consisted of six 65,000-horsepower pumps, each with the capacity to pump 1,600 cubic feet per second at 292 to 310 feet of head. These units pump water through 12-ft-diameter pipes into a 1.6-mile-long feeder canal (Figure 2.2), which discharges into Banks Lake. In the early 1960s, construction began on an additional six units. These units were designed to be reversible, where water could be returned from Banks Lake through these units to generate power during peak power demand periods. Units 7 and 8 are each rated at 67,500 horsepower, have the capacity to lift 1,605 cubic feet per second, and are each rated to generate 50 megawatts of power. Units 9-12 are rated at 70,000 horsepower, can lift 1,700 cubic feet per second in the pump mode, and each can generate 53.5 megawatts in the generating mode. The total generating capacity of the Grand Coulee PumpGenerating Plant is 314 megawatts.

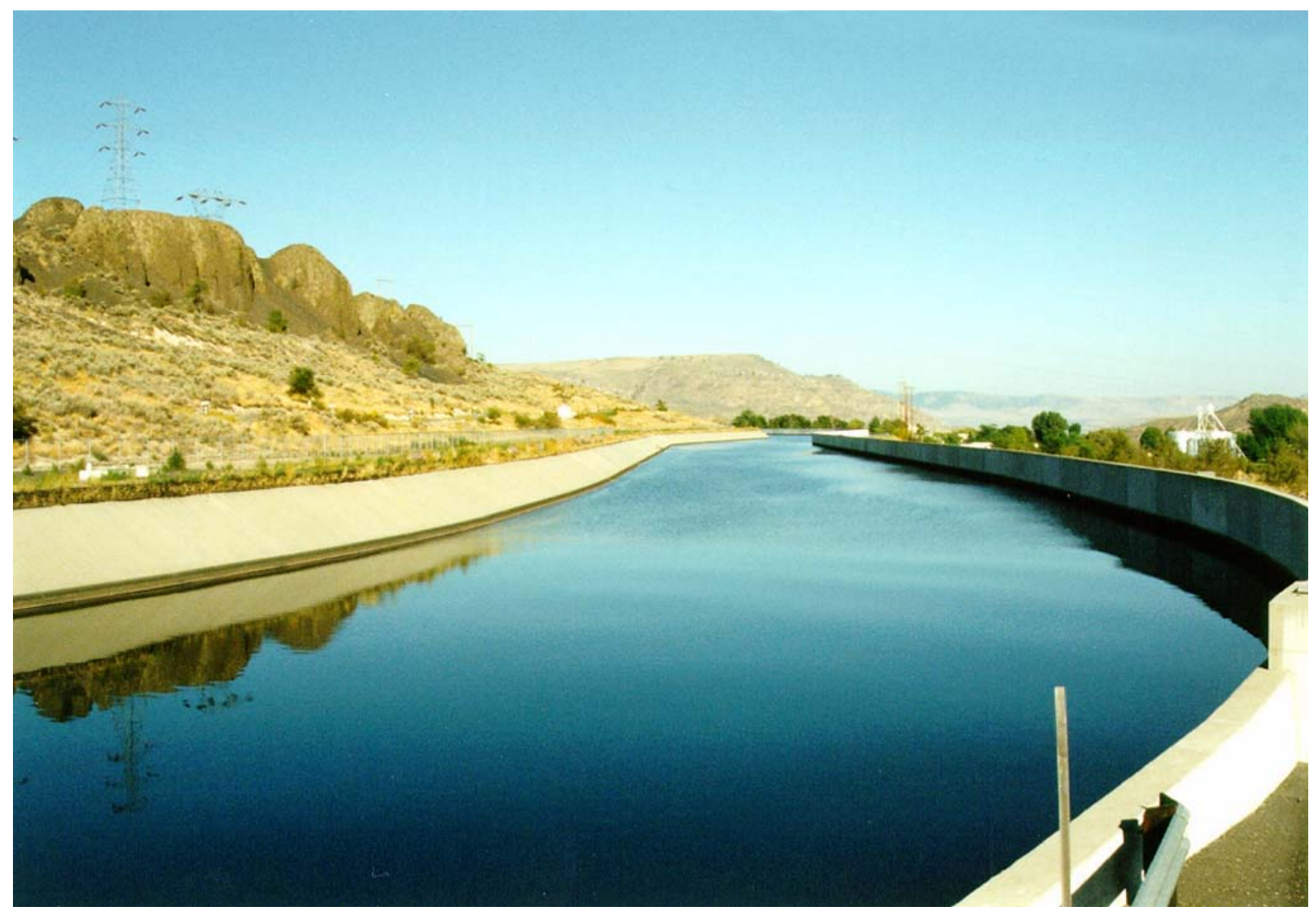

Figure 2.2. Canal carrying water from Lake Roosevelt through the pump-generating units to Banks Lake.

Recent modifications to the Pump-Generating Plant include replacement of some of the original pump-only runners with new runners that have nine vanes instead of seven. This change is being made to reduce pressure pulsations during pumping operations. Unit 5 of the Pump-Generating Plant, one of the pump-only units still equipped with an original seven-vane runner, was selected as the test pump for this study. 


\subsection{Sensor Fish Device}

The Sensor Fish Device (Figure 2.3), a waterproof, nearly neutrally buoyant sensor package developed by Battelle with funding from the U.S. Department of Energy's Advanced Hydropower Turbine System Program (Carlson and Duncan 2003), measures pressure and tri-axial acceleration as the sensor is carried with flow through a hydraulic environment. The sensor housing is constructed of clear polycarbonate plastic and is approximately $3.5 \mathrm{in}$. long and $0.75 \mathrm{in}$. in diameter. Digital samples of the sensor's analog outputs are taken every 0.005 sec over a period of up to 5.45 minutes as the sensor is carried with flow through the passage environment. Pressure samples are used to estimate the depth of the sensor and other hydraulic phenomena, while accelerometer output is used to measure the Sensor Fish's response to turbulence, strike, and scraping. The remainder of the Sensor Fish's electronics consists of rechargeable batteries, a power supply, an analog-to-digital converter, memory, and communication components. The digital samples acquired during passage are stored in a nonvolatile memory. The sensor memory is accessed after the Sensor Fish is recovered and the acquired data are downloaded to a computer for processing and analysis.

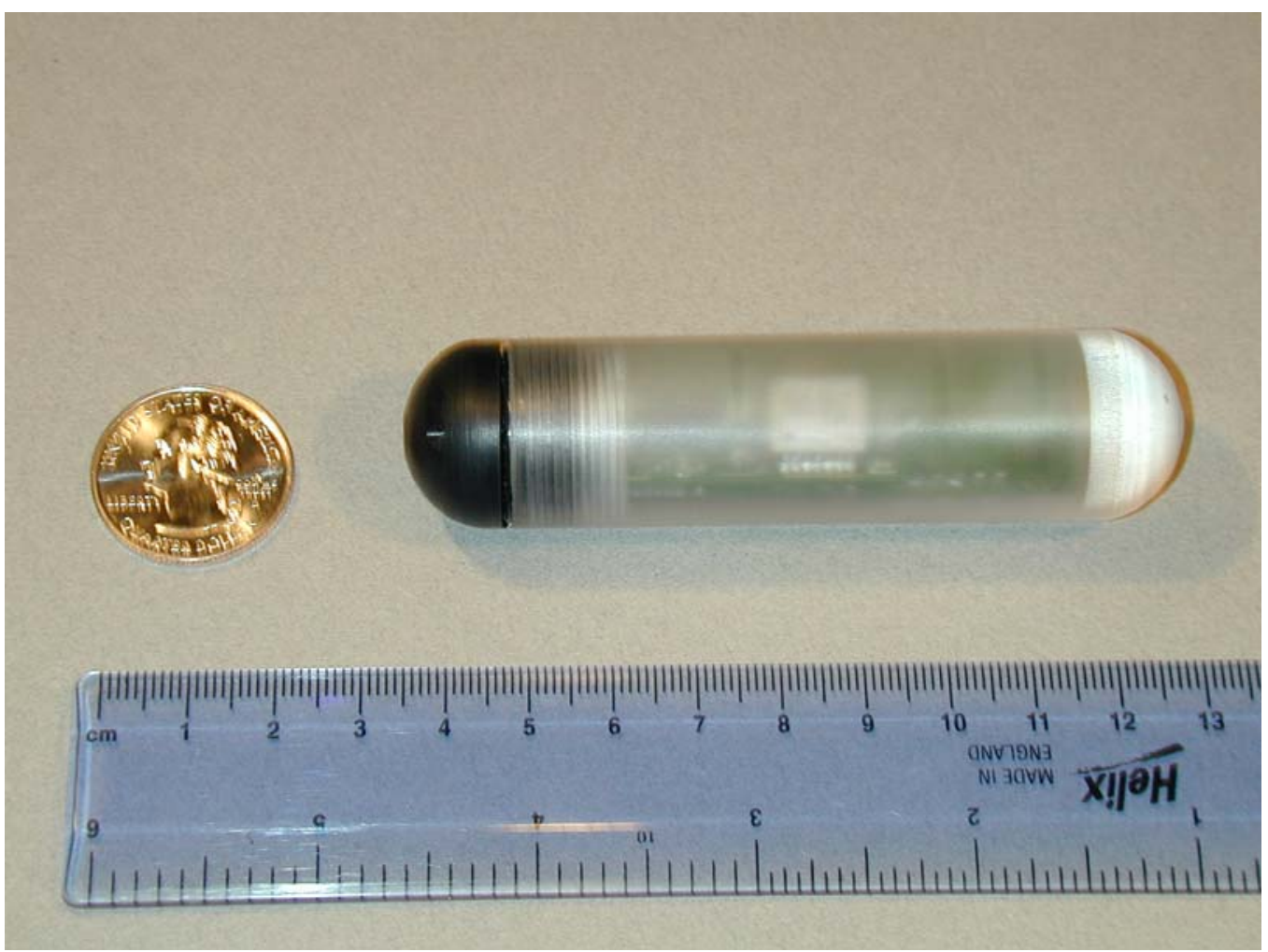

Figure 2.3. Sensor Fish Device.

Sensor Fish devices have an average mass of $42 \mathrm{~g} \pm 0.20 \mathrm{~g}$ (including buoyancy adjustment weight), a displacement of $43 \mathrm{ml} \pm 0.56 \mathrm{ml}$, and a density of $0.98 \mathrm{~g} / \mathrm{ml} \pm 0.01 \mathrm{~g} / \mathrm{ml}$. Sensor Fish are designed to be slightly positively buoyant in fresh water so that they slowly return to the surface following turbine passage. 


\subsection{Sensor Fish Releases}

Sensor Fish releases were made into Unit 5 of the pump generating plant. Prior to release, Sensor Fish were equipped with a radio frequency micro-transmitter and a light stick to aid recovery of the sensors when they exited the feeder canal and passed into Banks Lake. This location for sensor recovery was not optimum but was necessary because access to the feeder canal is restricted.

The means used to release Sensor Fish upstream of the pump unit involved lowering a guide cable, which extended from the intake deck of the pump-generating plant through an open inspection grating at the top of the pump unit 5 trash rack to a depth of 85 feet below the forebay elevation. The guide cable was held in position by a 75-pound weight. A borescope (pipe inspection camera) was attached to the guide cable so that its camera housing was immediately above the weight and aimed up toward the surface to observe the Sensor Fish as they were lowered. A hand winch was used to lower and raise the guide cable and weight. Sensor Fish were attached to an acoustic release device (referred to as an acoustic release device because the release was triggered by an acoustic signal) that was lowered along this guide cable by means of a rope. The release device was attached to the guide cable using hose clamps that were not completely tightened, allowing the release device to slide down the guide cable to the deployment depth of 84 feet (Figure 2.4). Borescope observations were used to verify the release of the Sensor Fish and the visual observations were recorded on video tape.

The Sensor Fish were programmed for a four-minute delay prior to initiation of data acquisition. Acquisition was set to the maximum collection time of 5.45 minutes. This delay time provided ample time to lower the Sensor Fish to the desired deployment depth. At the end of the delay period, the acoustic release was triggered and the Sensor Fish was released and began recording pressure and acceleration data as it traveled through the inlet pipe, up through the turbine runner, up the discharge pipe, and into the 1.6-mile feeder canal that discharges into Banks Lake.

PNNL and Colville Confederated Tribe staff in a boat stationed in Banks Lake recovered the Sensor Fish, aided by a directional radio receiver antenna used to home in on the radio transmitter attached to the Sensor Fish. 


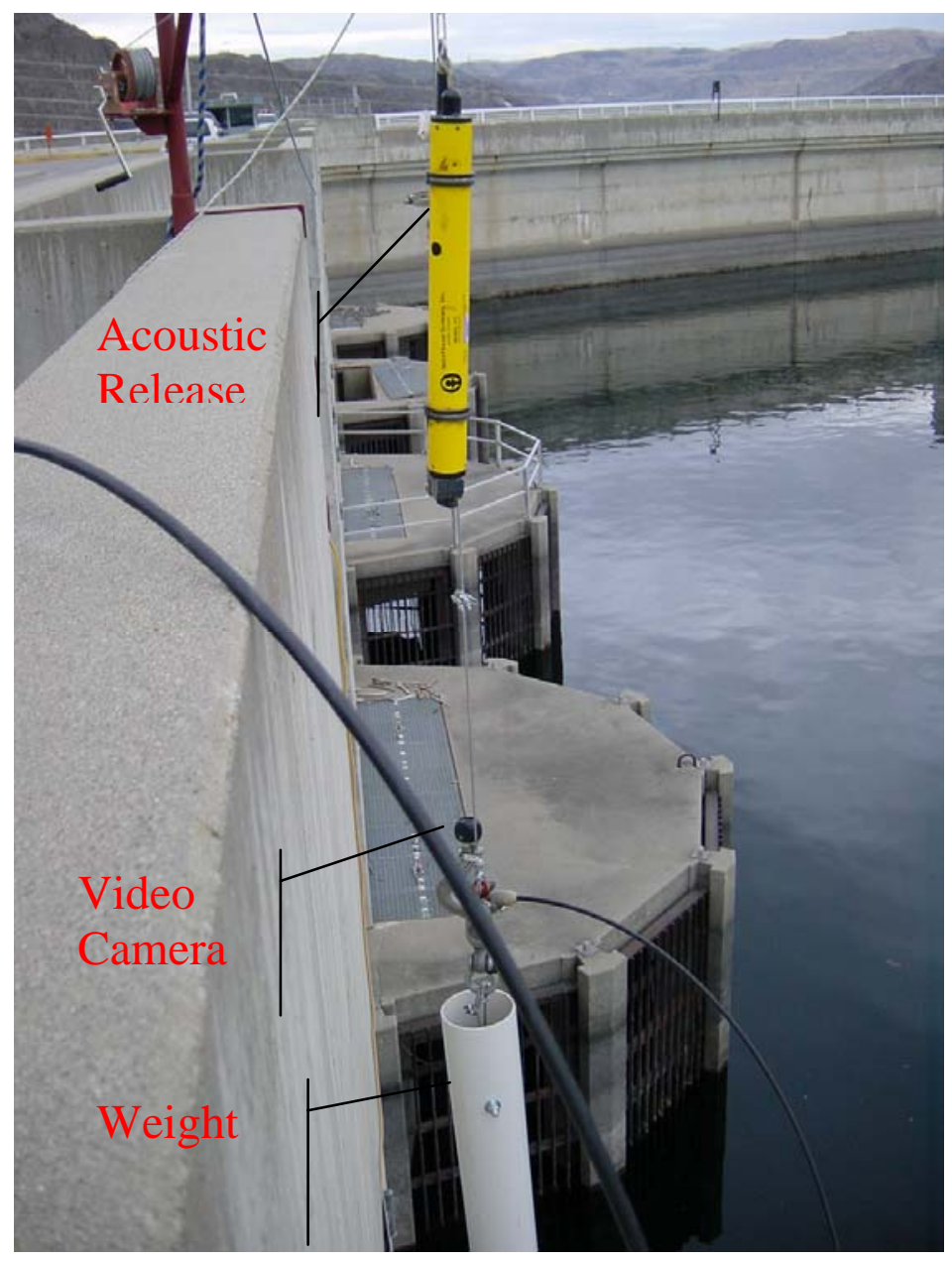

Figure 2.4. Apparatus used for deployment of Sensor Fish Devices into pump unit \#5. The weight was lowered by hand winch to a depth of approximately 90 feet using a 5/16" diameter stainless steel cable. The acoustic release with attached Sensor Fish Device was lowered using the cable as a guide to a depth of 84 feet where the Sensor Fish was released. A borescope video camera was used to observe all Sensor Fish releases.

\subsection{Data Acquisition and Analysis}

After passage through the pump unit, discharge pipe, and canal, the Sensor Fish were removed and the pressure and accelerometer data from each Sensor Fish release were downloaded and stored for analysis.

\subsubsection{Pressure Time Histories}

Pressure time histories have proven valuable for identifying Sensor Fish location during passage through hydraulic environments. In most dam passageways (spillways, turbines, sluiceways, fish bypass systems, etc.), pressure time histories contain consistent and easily identified features that are characteristic of pressure conditions at specific locations as the sensor is carried through the test environment. 
Pressure time series for the high slope section of the discharge pipe where the inclination of the pipe is known were analyzed to estimate the velocity magnitude for flow within the pipe. The rate of change in pressure reported by the Sensor Fish through this section of the discharge pipe was estimated by fitting a linear model to the pressure time series. These rates of change in pressure were converted to equivalent changes in depth using a conversion factor of 2.307 feet of water per psi. Estimates of change in elevation were adjusted for the inclination of the pipe to obtain the water velocity estimates. These estimates were made to compare sensor observations of travel time through the discharge pipe with theoretical estimates of travel time made using pump discharge data and the diameter of the test pump discharge pipe.

\subsubsection{Probability of Strike}

Strike by the blades or vanes of turbine runners is known to be a source of injury to fish passing through turbines either in generation or pump modes of operation (Cada et al. 1997). The probability of strike was estimated by comparing the time required for a simulated fish to pass into the turbine runner to the time required for the leading edge of a runner vane to reach the entry location of the fish between successive runner vane leading edges. The time required for a fish to pass was modeled as a function of the "exposure" length of the fish orthogonal to the vane leading edge assuming a random aspect in the plane orthogonal to the leading edges of the runner vanes.

At the extremes of orientation at approach to the intake vanes, a fish oriented parallel to the axis of the turbine runner would have an exposure length equal to its depth (or width, depending upon its rotation) while a fish oriented orthogonal to this axis would have an exposure length equal to its fork length (irrespective of its rotation). The variable modeled to estimate exposure length was the angle between the axis orthogonal to the runner central axis and the aspect of the fish. The fish's exposure length was the cosine of this angle multiplied by the fish's fork length. The time required for a fish to enter the turbine runner was estimated as the product of the velocity of the water in which the fish was entrained (the intake axial velocity) and the exposure length of the fish. The time required for the runner vane leading edge to reach the location where the fish crossed the arc circumscribed by the vane as it rotates was estimated by multiplying the speed of the vane in inches per second by the distance in inches from the vane leading edge to the fish's entry location. If the estimated time for the fish to enter the turbine runner was equal to or longer than the time required for the leading edge of the vane to reach the fish location, the fish was considered to have been struck by the vane.

Estimates of mean strike probability were obtained by Monte Carlo simulation. Fish exposure length and location of entry were modeled as random variables with uniform distributions. Fish fork length was modeled as a normally distributed random variable with a standard deviation equal to $10 \%$ of fish mean length. Fish mean lengths from 2.36 in. $(60 \mathrm{~mm})$ to $11.81 \mathrm{in.} \mathrm{(300} \mathrm{mm)} \mathrm{in} \mathrm{increments} \mathrm{of} 0.394$ in. (10 $\mathrm{mm}$ ) were modeled. The mean axial velocity of water entering the turbine was estimated by dividing the pumping rate in cubic feet per second by the circular cross-sectional area of the turbine intake. Water velocity was modeled as a normally distributed random variable with standard deviation equal to $10 \%$ of the mean axial velocity.

The factors that must be considered to estimate the probability of strike have been discussed elsewhere (Franke et al 1997, Ploskey and Carlson 2004) and will not be presented here. 


\subsection{Results}

Results from our field studies at Grand Coulee Dam Pump-Generating Plant are described below including water elevations at the site, pressure and acceleration data collected with the Sensor Fish, and strike probability analysis we conducted.

\subsection{Site Elevations}

A cross-section through the center line of a pumping unit at the Grand Coulee Pump-Generating Plant is shown in Figure 3.1 (Hubbard 1995). The release elevation for the Sensor Fish was 1,197 feet, just slightly above the centerline (elevation 1,193.27) of the 14-foot-diameter pipe leading from the Grand Coulee forebay to the pump. The release location was within the trashrack shown in the figure as the cage-like structure hanging on the front of the Pump-Generating Plant.

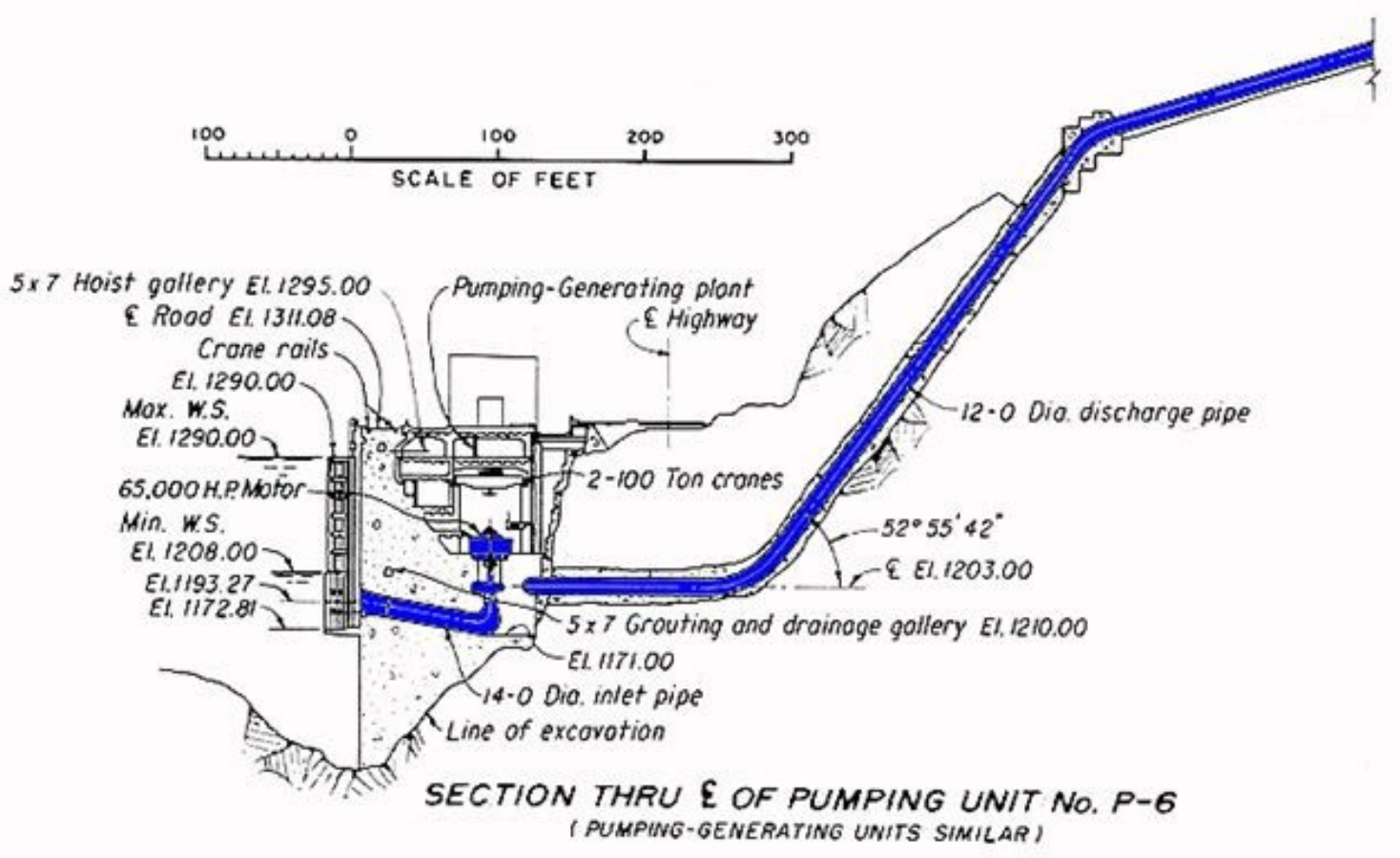

Figure 3.1. Cross-section through the centerline of pump unit \#6 at the Grand Coulee Pump-Generation Plant. Unit \#6 is identical to pump unit \#5, which was used for this study (Hubbard 1995).

At the time of the Sensor Fish releases, on September 12, 2004, the elevations of Lake Roosevelt at the powerhouse and of Banks Lake were 1,280.6 ft and 1,567.3 ft respectively (data from USACE Water Control Center web site http://www.nwd-wc.usace.army.mil/ftppub/project_data/daily/gcl.txt). The total change in elevation between the center line of the pump and the elevation of the Banks Lake water surface was $364.3 \mathrm{ft}$ at the time of the Sensor Fish data acquisition. 


\subsection{Pressure and Acceleration Time Histories}

Figure 3.2 is one of the pressure time histories acquired during the study. The graphic is annotated to describe the location of the Sensor Fish at specific times during its passage in pump flow. Figures 3.3, 3.4, and 3.5 show the gage pressure in psi and acceleration magnitude in $\mathrm{g}$ for three Sensor Fish releases. Table 3.1 contains data extracted from the sensor pressure and acceleration histories that aid in assessing the impacts to fish that are entrained in pump flow.

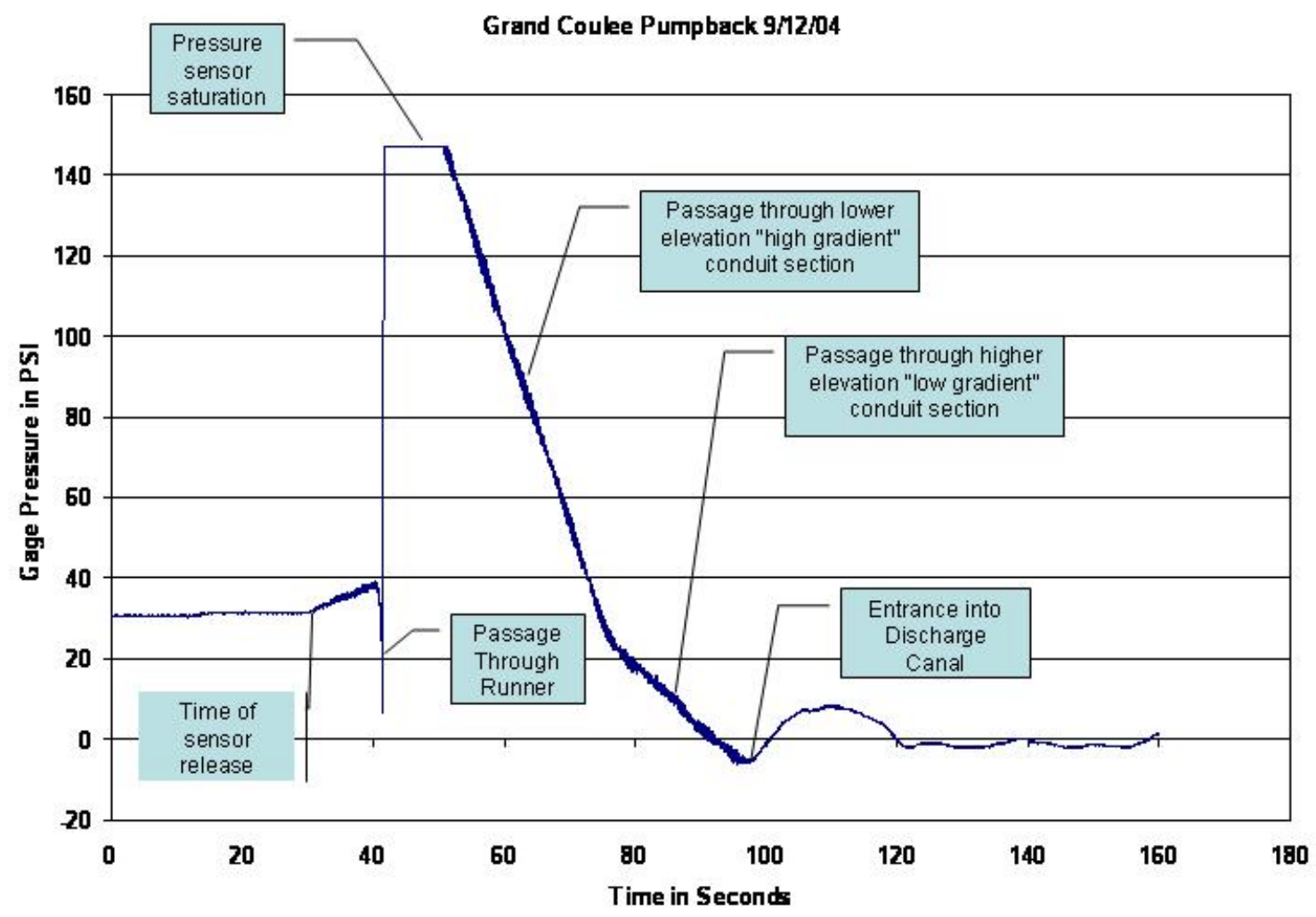

Figure 3.2. Example gage pressure time history for a Sensor Fish passage through pump unit \#5. The text blocks describe the location of the Sensor Fish during passage. 


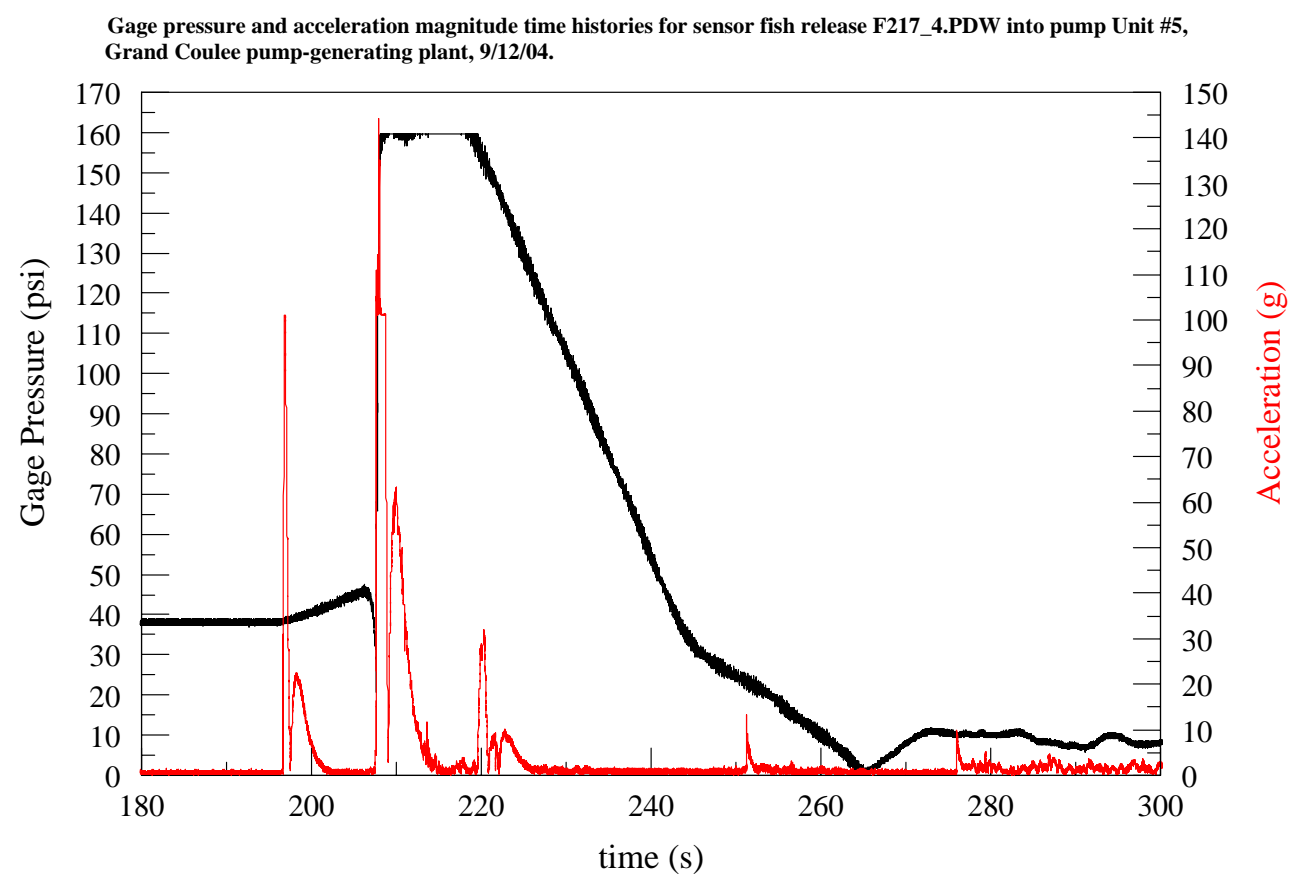

Figure 3.3. Gage pressure and acceleration magnitude time histories for passage of Sensor Fish release F217_4 through pump unit \#5, the pump discharge pipe, and entry into the Banks Lake feeder canal.

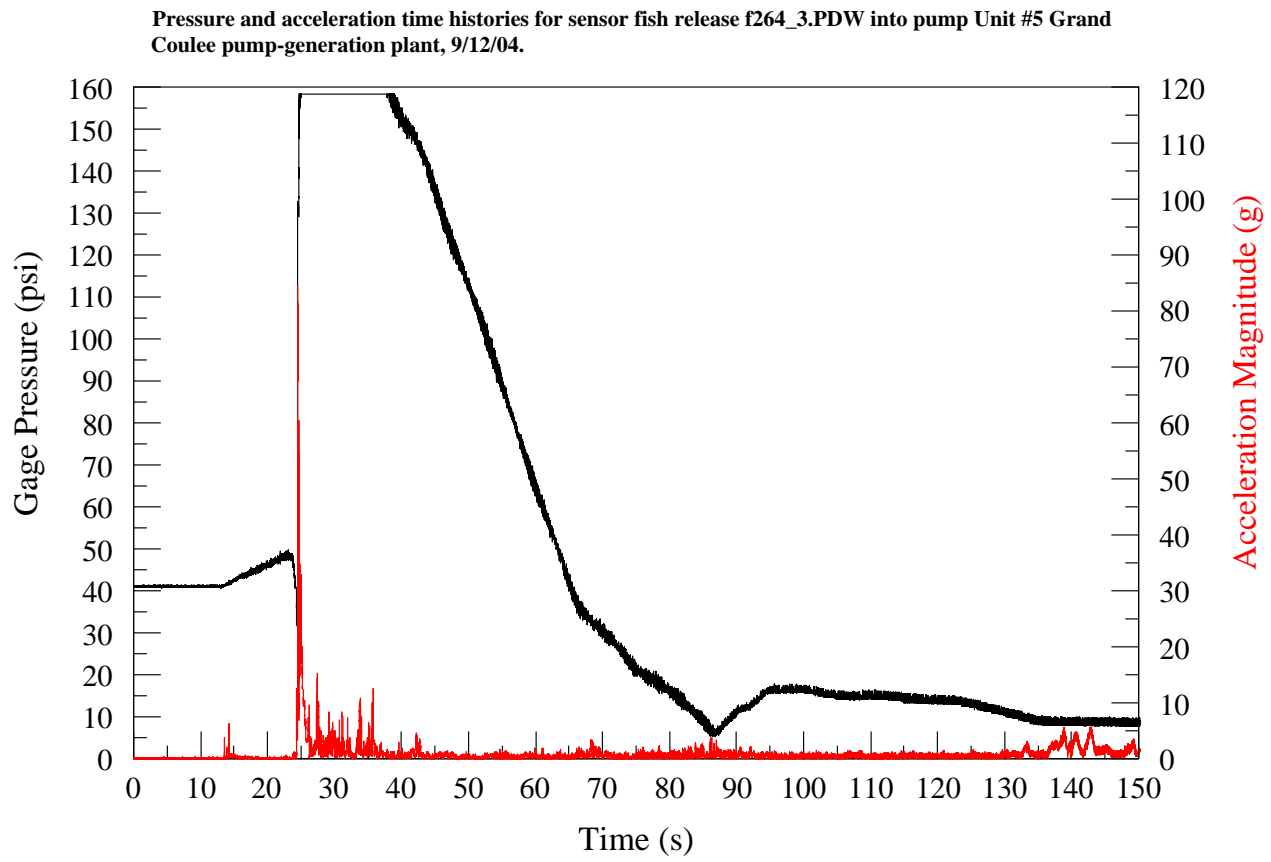

Figure 3.4. Gage pressure and acceleration magnitude time histories for passage of Sensor Fish release F264_3 through pump unit \#5, the pump discharge pipe, and entry into the Banks Lake feeder canal. 


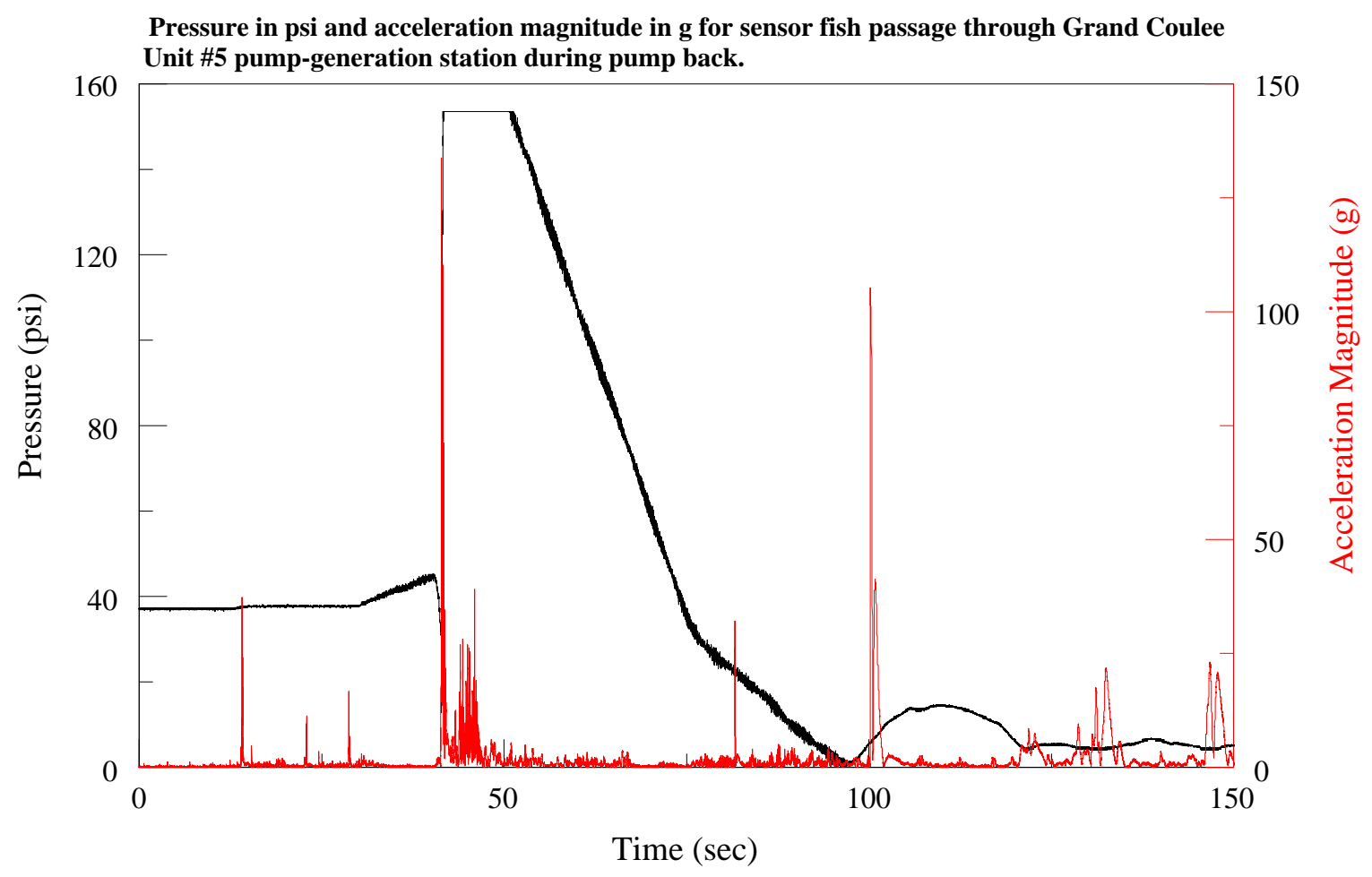

Figure 3.5. Gage pressure and acceleration magnitude time histories for passage of Sensor Fish release F264_2 through pump unit \#5, the pump discharge pipe, and entry into the Banks Lake feeder canal.

Table 3.1. Estimates of various passage exposure metrics abstracted from pressure and acceleration magnitude time histories recovered from successful Sensor Fish releases through pump unit \#5 at the Grand Coulee Pump-Generation Plant

\begin{tabular}{|c|c|c|c|}
\hline \multirow{2}{*}{ Measurement } & \multicolumn{3}{|c|}{ Sensor Identification Number } \\
\hline & f 2174 & f 264_2 & f 264_3 \\
\hline Minimum Pressure (psi) & 18.81 & 6.384 & 12.375 \\
\hline Max negative rate of change in pressure (psi/sec) & 36.37 & 39.03 & 34.31 \\
\hline Maximum pressure (psi) & $155.00^{\star}$ & 155.00 & 155.00 \\
\hline Max positive rate of change in pressure (psi/sec) & 392.10 & 530.85 & 433.00 \\
\hline Time from release to minimum pressure (sec) & 11.01 & 12.67 & 10.19 \\
\hline Time from minimum pressure to maximum pressure $(\mathrm{sec})$ & 0.52 & 0.27 & 0.32 \\
\hline Time in level section of discharge conduit (sec) & 11.53 & 9.63 & 14.11 \\
\hline Time in high-slope section of discharge conduit (sec) & 26.73 & 26.67 & 28.59 \\
\hline Time in low-slope section of discharge conduit (sec) & 19.66 & 19.70 & 19.68 \\
\hline Time from minimum pressure to entrance of discharge canal (sec) & 58.27 & 56.26 & 62.70 \\
\hline $\begin{array}{l}\text { Turbulence duration from minimum pressure through level section } \\
\text { of discharge pipe (sec) }\end{array}$ & 1.28 & 1.04 & 1.04 \\
\hline $\begin{array}{l}\text { Turbulence magnitude from minimum pressure through level } \\
\text { section of discharge pipe (ft/sec } 2 \text { ) }\end{array}$ & $3.30 \mathrm{E}+05$ & $6.91 \mathrm{E}+04$ & $7.89 \mathrm{E}+04$ \\
\hline
\end{tabular}


Pressure time series for the high slope section of the discharge pipe where the inclination of the pipe is known (Figure 3.1) were analyzed to estimate the velocity magnitude for flow within the pipe. This analysis was conducted assuming that the Sensor Fish is fully entrained in flow and is moving at the same velocity as the bulk flow in the discharge pipe. The inclination from horizontal of the high slope region of the pipe is given in Figure 3.1 as $52^{\circ} 55^{\prime} 42^{\prime \prime}$ ( $52.928^{\circ}$ or $\left.0.9238 \mathrm{rad}\right)$. The rate of change in pressure reported by the Sensor Fish through this section of the discharge pipe was estimated by fitting a linear model to the pressure time series. The slope estimates obtained for the three data sets are given in Table 3.2. In all cases, correlation coefficients for fit were better than 0.99. These rates of change in pressure were converted to equivalent changes in depth using a conversion factor of 2.307 feet of water per psi. Estimates of change in elevation were adjusted for the inclination of the pipe to obtain the water velocity estimates, also presented in Table 3.2. These estimates of water velocity are very comparable to that expected (14 to $15 \mathrm{ft} / \mathrm{sec}$ ) given the pumping rate (1.6 kcfs) and the cross-sectional area of the 12foot-diameter discharge pipe.

Table 3.2. Estimates of rate of change in pressure and water velocity for the high-slope section of the pump \#5 discharge pipe.

\begin{tabular}{|c|c|c|}
\hline Sensor ID & $\begin{array}{c}\text { Rate of Change in } \\
\text { Pressure (psi/sec) }\end{array}$ & $\begin{array}{c}\text { Water Velocity } \\
\text { Estimate }(\mathrm{ft} / \mathrm{sec})\end{array}$ \\
\hline F264_2 & -4.7253 & 13.66 \\
\hline F264_3 & -4.8833 & 14.12 \\
\hline F217_4 & -5.0556 & 14.62 \\
\hline
\end{tabular}

The conditions for passage of fish through pump \#5 showed a short duration of relatively low turbulence. Following a short period of medium-level turbulence, on the order of 500 milliseconds (0.5 $\mathrm{sec})$, which begins at the runner and extends into the flat slope region immediately upstream of the runner, the sensor experienced a very low level of turbulence.

The gage pressure observed during Sensor Fish passage shows the approach to the runner, the low pressure at the suction side of the runner, and the transition to the higher pressure on the upstream side of the runner (Figure 3.6). Pressures from approximately 6 to 18 psi gage were observed on the suction side of the runner. Following this low pressure, there was a rapid increase in pressure over an approximate 200-millisecond period to more than 155 psi gage. The pressure sensor in the Sensor Fish saturated at 155 psi and stopped acquiring data for approximately five seconds until it finished passing through the runner and began ascending the conduit (see Figure 3.2).

\subsection{Estimation of Strike Probability for Fish Entrained in Pump Flow}

Strike by the blades or vanes of turbine runners is known to be a source of injury to fish passing through turbines either in generation or pump modes of operation. The seven-bladed runners in the original pumps at the Grand Coulee Pump Generation Station are being replaced by nine-bladed runners to reduce pressure pulsations during pump operations. The test unit for this study, unit \#5, still retains its original seven-bladed runner. One of the seven-bladed runners that was removed and replaced with a new runner has been placed in a park near the dam. Photographs of that runner are shown in Figures 3.7 through 3.10. In the photographs, the runner is sitting upside down on the ground. The narrower end is the 
intake and the wider end (in contact with the ground) is the discharge when the runner is installed as designed. It is worth noting that these runners differ considerably in size and design from those installed at the third powerhouse (Figure 3.11).

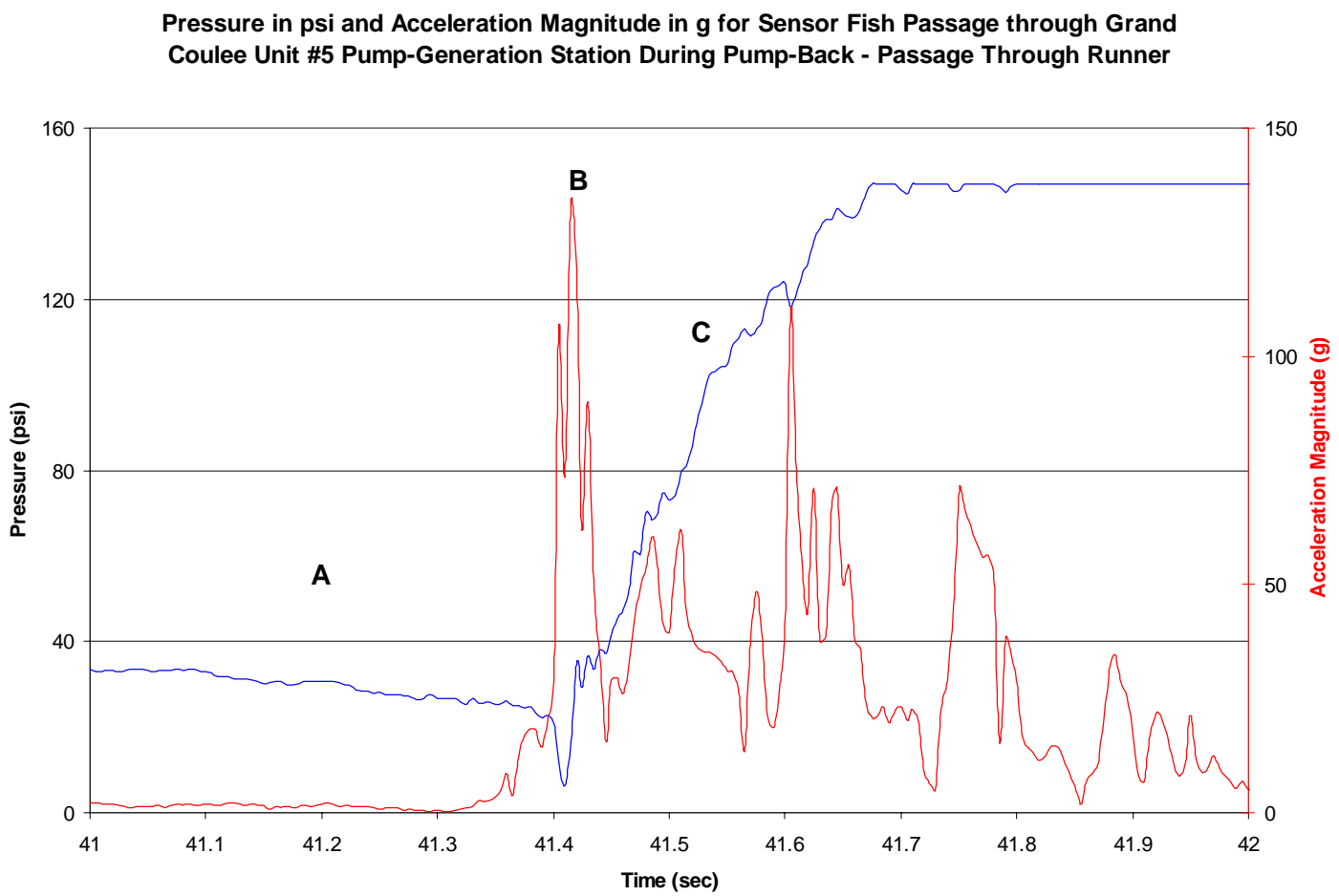

Figure 3.6. A portion of a Sensor Fish's gage pressure and acceleration magnitude time histories (F264_2) during passage through pump unit \#5. This 1-second time segment shows (a) the approach and passage of the sensor through (b) the pump runner and (c) the region in the discharge pipe immediately downstream of the runner. The pressure data goes flat at 41.8 seconds when the pressure sensor is saturated.

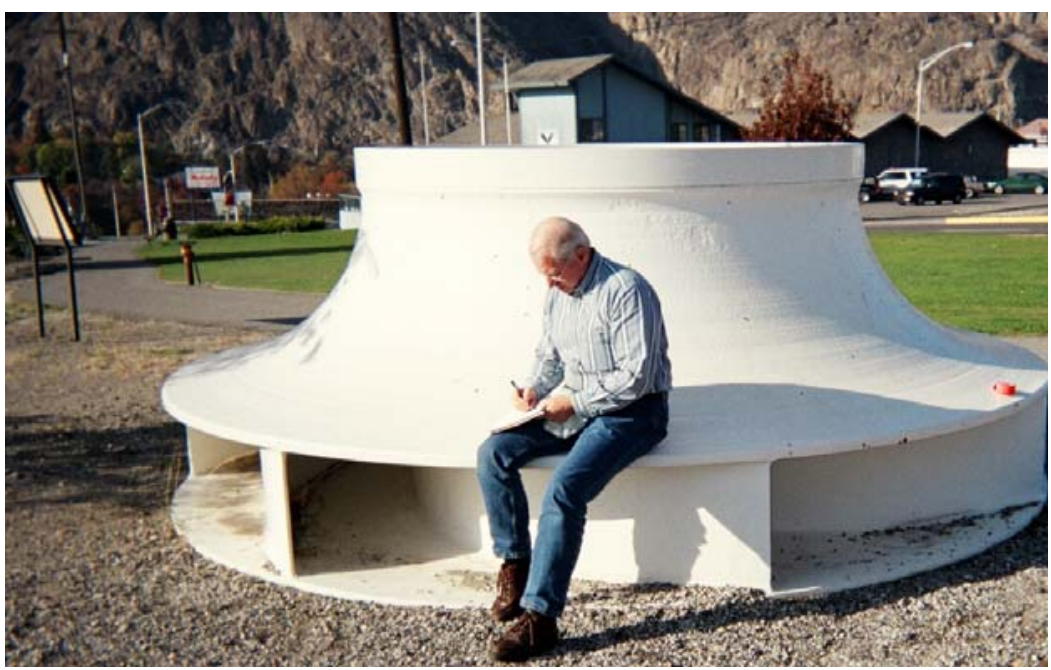

Figure 3.7. Photograph of an original seven-vane design pump runner for pump units 1-6 at the Grand Coulee Pump-Generation station. The runner is sitting upside down in the photograph. 


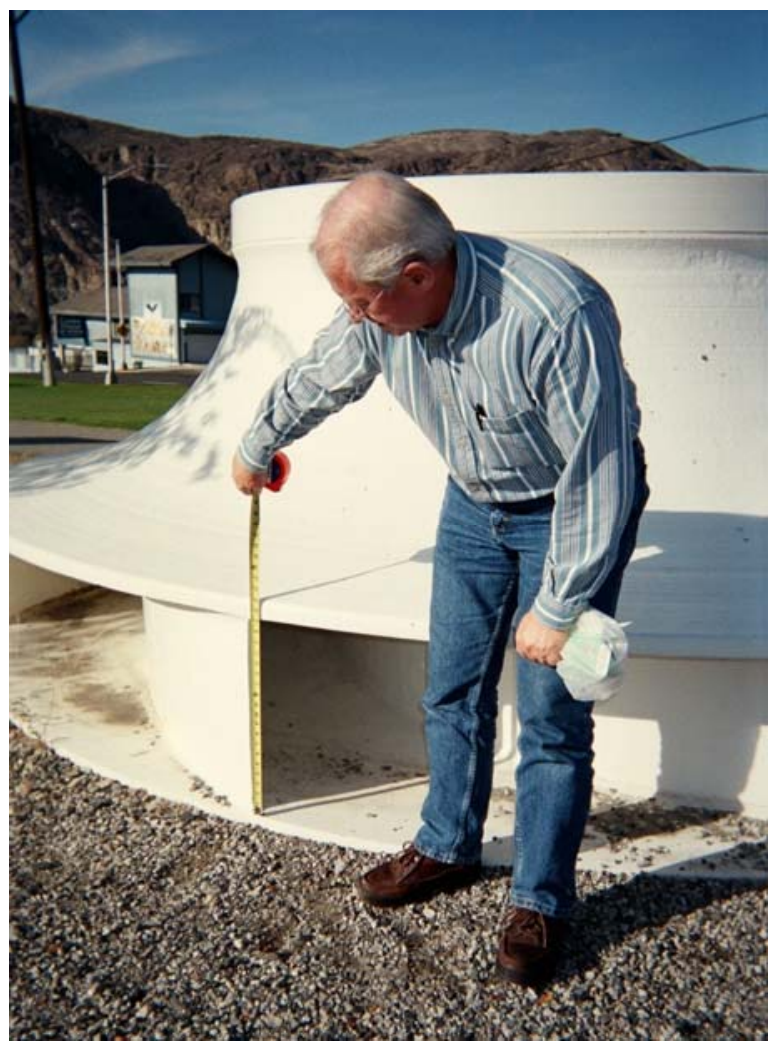

Figure 3.8. Measuring the height of the discharge leading edge of the pump runner vane.

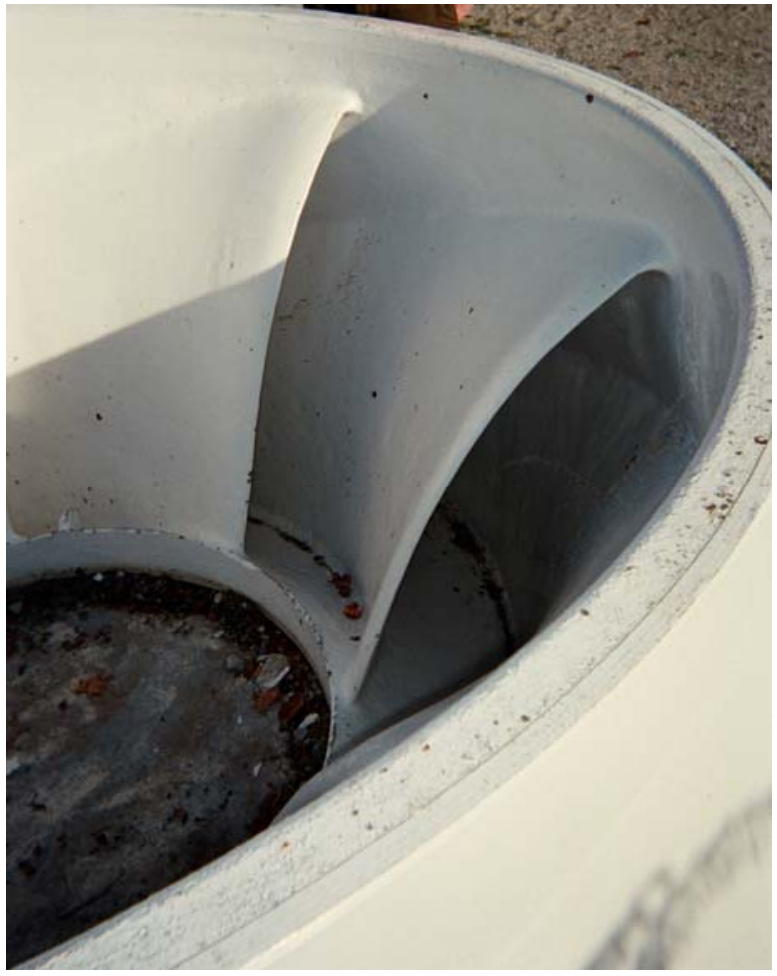

Figure 3.9. View looking into the intake of the pump runner showing the openings of the runner vanes. 


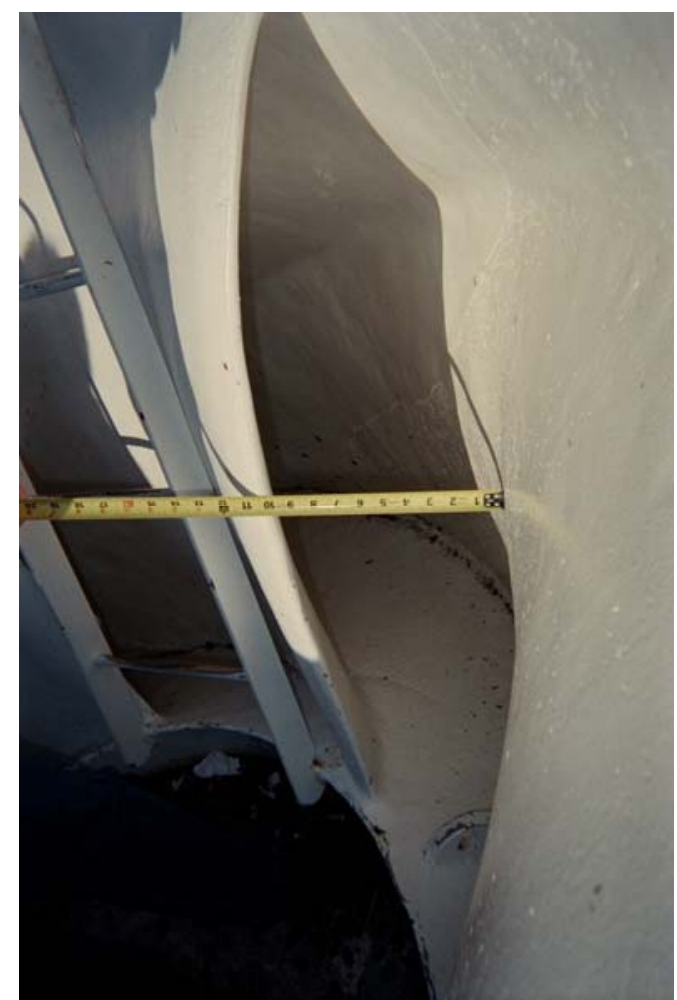

Figure 3.10. Measuring the width of the opening of the pump intake vanes. (The ladder shown in the picture is not a normal part of the runner.)

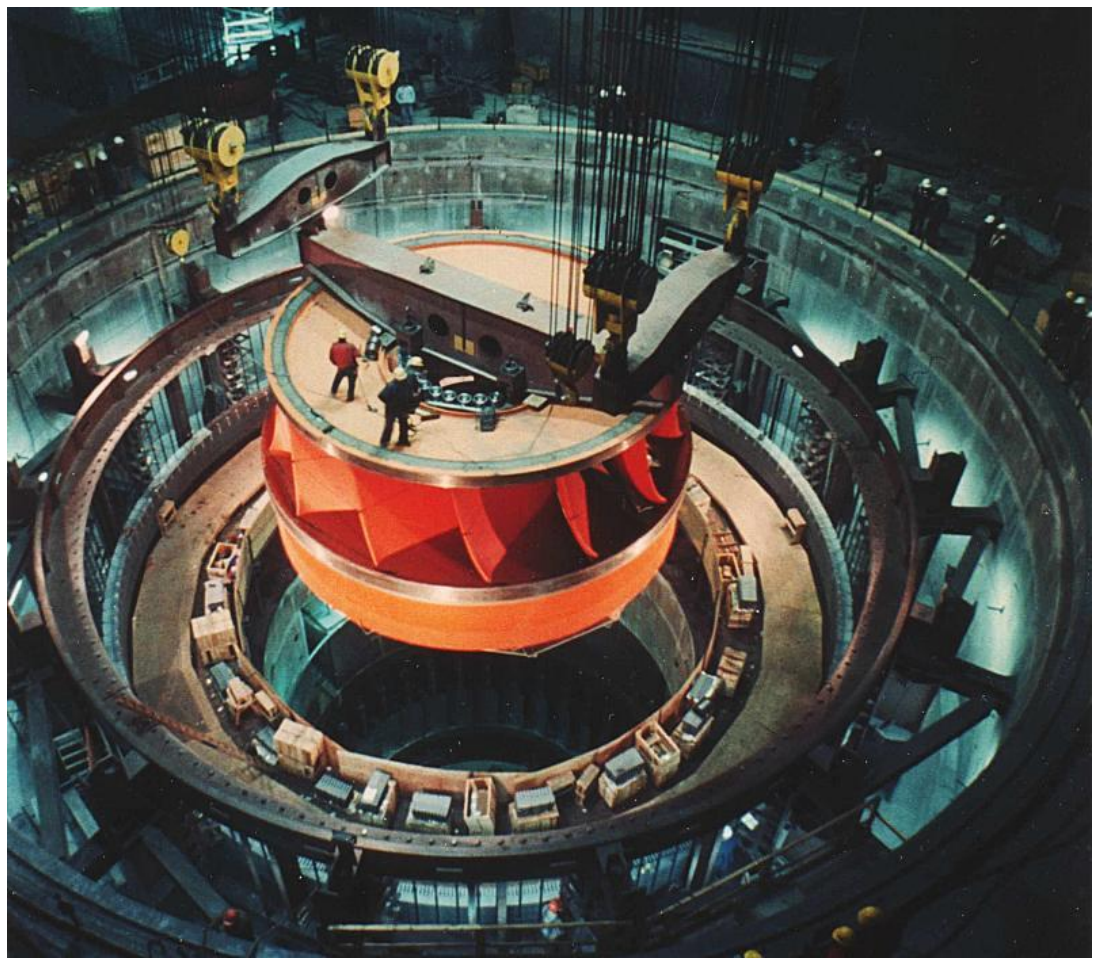

Figure 3.11. Installation of a Francis runner at the Third Powerhouse at Grand Coulee Dam. 
We made a number of measurements of this seven-bladed runner on November 10, 2004, during a visit to Grand Coulee Dam. These measurements, in conjunction with other information we obtained during a meeting with a member of the Grand Coulee engineering staff, are summarized in Table 3.3.

Table 3.3. Measurements of physical features of an original seven-bladed pump runner identical to that in test pump unit \#5.

\begin{tabular}{|l|c|}
\hline \multicolumn{1}{|c|}{ Item } & Metric \\
\hline Number of vanes & 7 \\
\hline Runner speed & $200 \mathrm{rpm}$ \\
\hline Pumping rate & $1.6 \mathrm{kcfs}$ \\
\hline Diameter of runner at its intake & 7.5 feet (90 inches) \\
\hline Diameter of runner at its discharge & 14 feet \\
\hline Vane edge height at discharge & 1.583 feet (19 inches) \\
\hline
\end{tabular}

The results of the Monte Carlo simulations are shown in the graph in Figure 3.12 and Table 3.4. Strike probability ranged from 0.755 for 2.36 -inch $(60 \mathrm{~mm})$ fish to 0.3890 for 11.81 -inch $(300 \mathrm{~mm})$ fish.

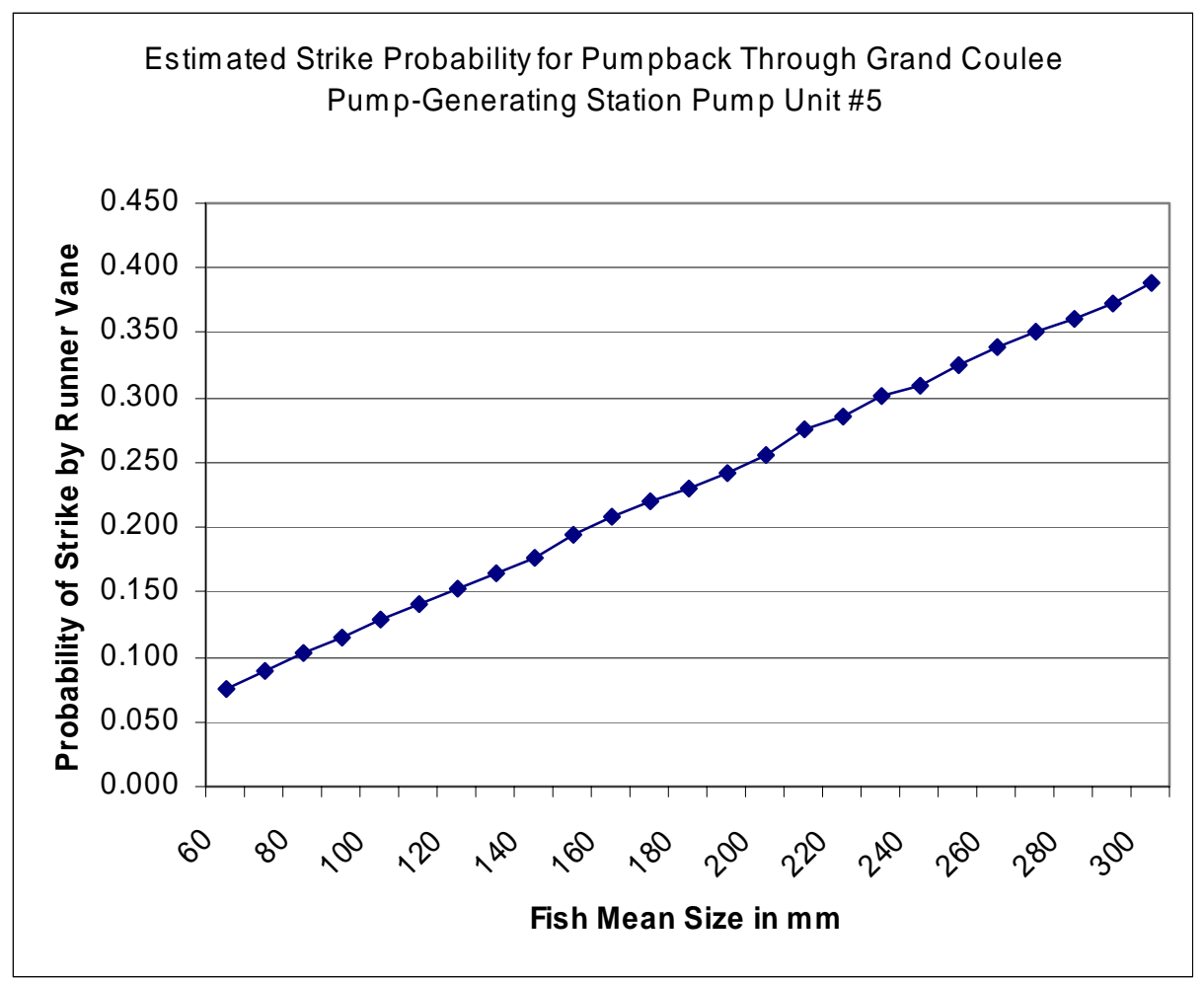

Figure 3.12. Plot of the estimates of strike probability as a function of fish size for passage through the seven-vane pump runner of pump unit \#5 at the Grand Coulee Pump-Generation Plant. 
Table 3.4. Estimates of strike probability as a function of fish size for passage through the seven-vane pump runner of pump unit \#5 at the Grand Coulee Pump-Generation Plant.

\begin{tabular}{|c|c|c|c|c|}
\hline \multicolumn{4}{|c|}{ Fish Length } & \multirow{3}{*}{ Strike Probability } \\
\hline \multicolumn{2}{|c|}{ Inches } & \multicolumn{2}{|c|}{$\mathbf{m m}$} & \\
\hline Length & SD & Length & SD & \\
\hline 2.36 & 0.24 & 60.00 & 6.00 & 0.0755 \\
\hline 2.76 & 0.28 & 70.00 & 7.00 & 0.0899 \\
\hline 3.15 & 0.31 & 80.00 & 8.00 & 0.1038 \\
\hline 3.54 & 0.35 & 90.00 & 9.00 & 0.1141 \\
\hline 3.94 & 0.39 & 100.00 & 10.00 & 0.1285 \\
\hline 4.33 & 0.43 & 110.00 & 11.00 & 0.1409 \\
\hline 4.72 & 0.47 & 120.00 & 12.00 & 0.1519 \\
\hline 5.12 & 0.51 & 130.00 & 13.00 & 0.1651 \\
\hline 5.51 & 0.55 & 140.00 & 14.00 & 0.1773 \\
\hline 5.91 & 0.59 & 150.00 & 15.00 & 0.1936 \\
\hline 6.30 & 0.63 & 160.00 & 16.00 & 0.2077 \\
\hline 6.69 & 0.67 & 170.00 & 17.00 & 0.2196 \\
\hline 7.09 & 0.71 & 180.00 & 18.00 & 0.2300 \\
\hline 7.48 & 0.75 & 190.00 & 19.00 & 0.2420 \\
\hline 7.87 & 0.79 & 200.00 & 20.00 & 0.2556 \\
\hline 8.27 & 0.83 & 210.00 & 21.00 & 0.2748 \\
\hline 8.66 & 0.87 & 220.00 & 22.00 & 0.2859 \\
\hline 9.06 & 0.91 & 230.00 & 23.00 & 0.3005 \\
\hline 9.45 & 0.94 & 240.00 & 24.00 & 0.3097 \\
\hline 9.84 & 0.98 & 250.00 & 25.00 & 0.3261 \\
\hline 10.24 & 1.02 & 260.00 & 26.00 & 0.3381 \\
\hline 10.63 & 1.06 & 270.00 & 27.00 & 0.3514 \\
\hline 11.02 & 1.10 & 280.00 & 28.00 & 0.3616 \\
\hline 11.42 & 1.14 & 290.00 & 29.00 & 0.3723 \\
\hline 11.81 & 1.18 & 300.00 & 30.00 & 0.3890 \\
\hline
\end{tabular}




\subsection{Discussion}

The conditions for passage of fish through pump unit \#5 were, with the exception of the immediate runner environment, and the low pressure on the suction side of the pump, good. Following a short period of medium-level turbulence, on the order of 500 milliseconds $(0.5 \mathrm{sec})$, which begins at the runner and extends into the flat slope region immediately upstream of the runner, the sensor experienced a very low level of turbulence. The duration and magnitude of the turbulence observed with the sensor was comparable with that observed for sensor passage through much larger Kaplan turbines (Figure 4.1) and much less than that observed in spill passage routes (Figure 4.2) (Carlson and Duncan 2004). These observations of exposure conditions would indicate that the risk of injury to fish from turbulence exposure is low for the operations and particular pump sampled.

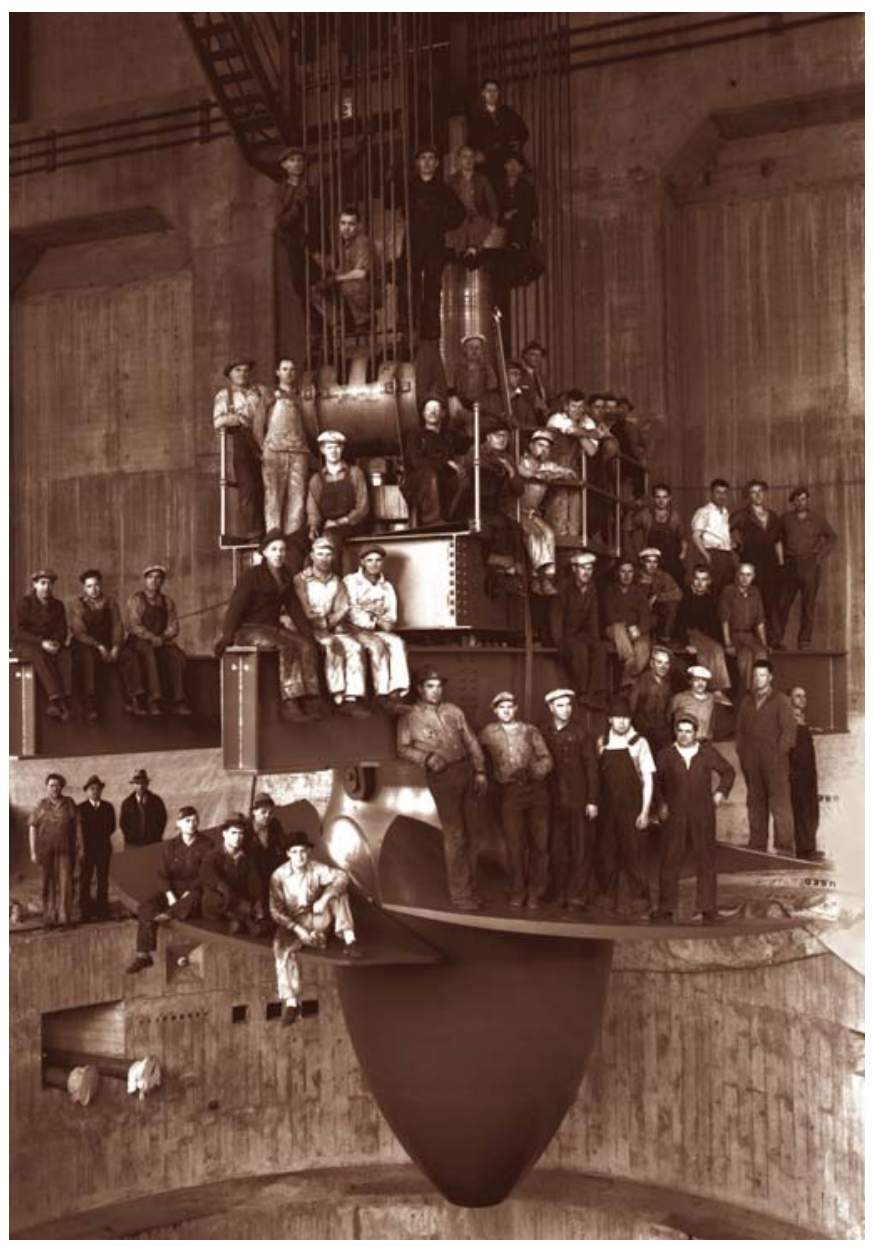

Figure 4.1. One of the original Kaplan turbine runners installed in the later 1930s at the Bonneville Dam first powerhouse. This runner is typical of those installed at most dams below Chief Joseph Dam on the mainstem Columbia River. 


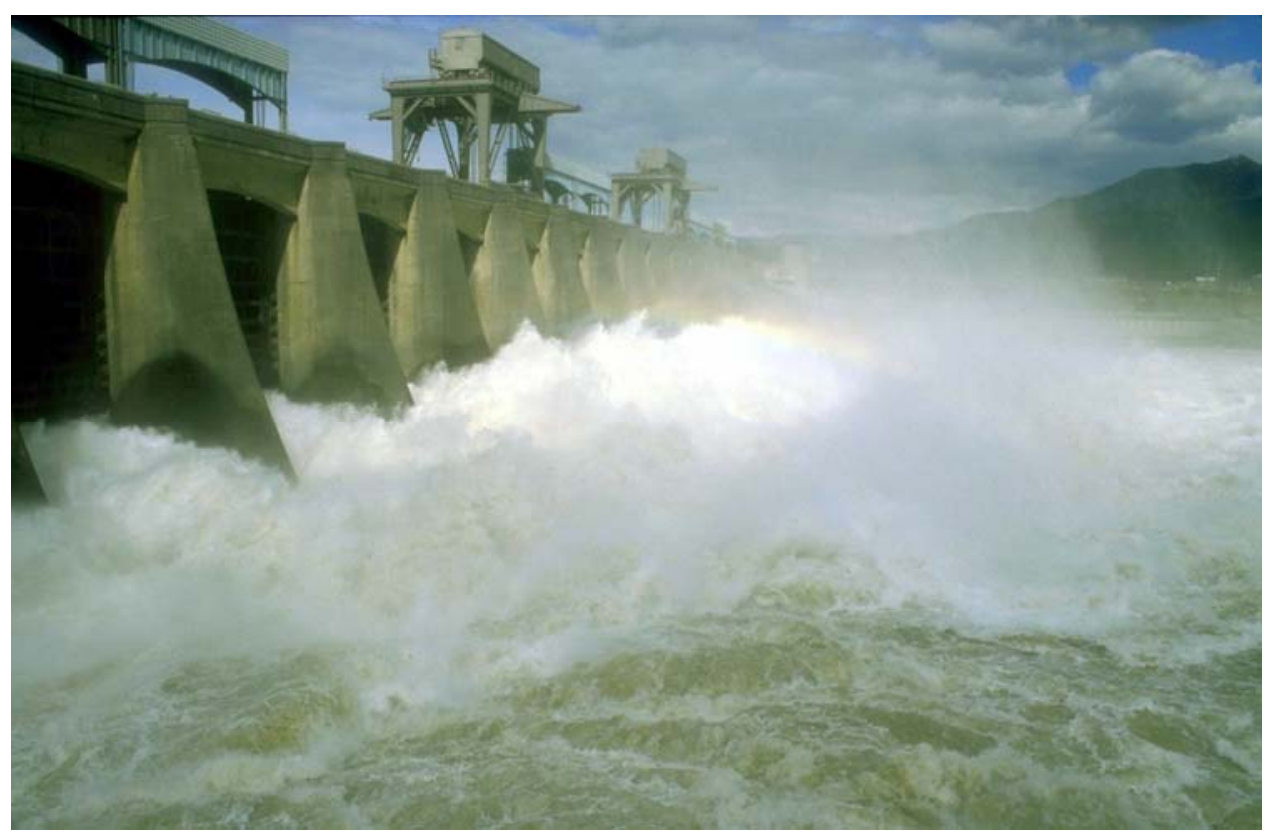

Figure 4.2. Spill discharge for fish passage at Bonneville Dam.

The expected highest pressure the Sensor Fish would experience would be the static pressure due to the difference in water level between the water elevation in the discharge canal at the top of the conduit and the location of the sensor when it was located at the base of the conduit just after exiting the scroll case in the 12-foot-diameter discharge pipe plus the pressure effects of water velocity (velocity head). This difference between the discharge canal water surface elevation and the location of the sensor after passage through the pump was nearly 364 feet when the pressure data was acquired. This height of water over the sensor would amount to a pressure of approximately 157 psi, only slightly higher than the 155 psi level at which the sensor saturated (Figures 3.2 and 3.6).

Cada et al. 1997 summarized the findings of the effects of pressure during turbine passage on fish. His summary of research conducted to the date of his review is that both physoclistous and physostomous fish can withstand the large sudden increases in pressure that typically occur in hydroturbines without death or injury. However, the same has not been found for decreases in pressure. Rapid decreases in pressure may cause the fish's swimbladder to enlarge (distend), which can cause injury to other tissues as well as result in swimbladder rupture. Both physostomous and physoclistous fish are vulnerable to injury from rapid decreases in pressure with physoclistous fish being much more so because they lack a vent for rapid expulsion of swimbladder gas. Research indicates that both types of swimbladder fish are protected from swimbladder-related injuries if the minimum pressures experienced are no less than $60 \%$ of the pressure to which they are acclimated. In the case of being pumped through unit \#5 at the Grand Coulee Pump-Generating Plant, fish acclimated to pressure less than approximately 15 psi would likely pass without pressure injuries. This pressure corresponds to a depth of approximately 34.6 feet $(10.5 \mathrm{~m})$. The predominant depth of fish detected during mobile hydroacoustic surveys in the Pump-Generating Plant forebay in 2004 was approximately 30 to 130 feet (10 to 40 meters) (Johnson et al. 2005). If some of the detected fish were kokanee acclimated for neutral buoyancy at these depths and passed through the pump, it is possible that some of these fish might have been injured or killed by changes in pressure during passage through the pump. 
The findings reported by Cada (1997) for surface-acclimated salmonids were largely confirmed in recently completed pressure cycle testing of Chinook salmon juveniles and rainbow trout. Tests conducted using a hyperbaric chamber and exposing physoclistous bluegill and physostomous salmonids, Chinook salmon and rainbow trout, to pressures as low as 10 psi found that if dissolved gas supersaturation is not a problem, brief low pressure will cause little direct mortality among surfaceacclimated salmonids (Abernethy et al. 2001). However, a pilot-scale study recently completed suggests that low pressure exposure may cause direct mortality among depth-acclimated salmonids ${ }^{1}$ (Carlson and Abernethy, in draft); however, these studies are not complete and conclusions have not been drawn about increased risk of mortality for pressure-cycled depth-acclimated salmonids. Until then, conclusions about the possible effects of exposure of kokanee to low pressure at the suction side of pumps at Grand Coulee, in the absence of studies to resolve the issue for kokanee at Grand Coulee, will remain uncertain.

As expected, the probability of strike (Figure 3.12, Table 3.4) increases in direct proportion to fish mean length under the assumptions and conditions of analysis. Strike probability ranged from 0.0755 for 2.36-inch $(60 \mathrm{~mm})$ fish to 0.3890 for 11.81 -inch $(300 \mathrm{~mm})$ fish. Juvenile kokanee released from hatcheries into Lake Roosevelt have mean lengths ranging from about 5.51 inches $(140 \mathrm{~mm})$ to 7.09 inches $(180 \mathrm{~mm})$. Adult kokanee caught in Lake Roosevelt range between 9.84 inches $(250 \mathrm{~mm})$ and 15.75 inches $(400 \mathrm{~mm}$ ) in length with a mean length of approximately 12.8 inches (325 mm). Adult females are slightly smaller than adult males (McLellan et al. 2003).

The probability of strike estimates, given the length information presented above, indicate that the majority (77\%) of recently released kokanee $(180 \mathrm{~mm})$, if entrained in pump flows, would be carried through the pump without being struck and, most likely, without significant injury resulting from turbulence exposure. Uncertain is the injury or mortality resulting from exposure to low pressure, primarily because the acclimation depth of kokanee entrained in pump flow is not known and testing of pressure cycling of depth-acclimated salmonids is incomplete. Of the $23 \%$ that might be struck, it is expected, given experience with the rate at which struck fish are injured or killed (Turnpenny 1998, Turnpenny et al. 1992, Turnpenny et al. 2000), that the majority of these fish (60\% or so) would also arrive in Banks Lake without visible external injuries. In total, it would be expected that in excess of $90 \%$ of 7.09-inch $(180 \mathrm{~mm})$ kokanee juveniles entrained in pump flow would arrive in Banks Lake without significant injury if not predated upon in the discharge canal or otherwise lost prior to entry into the lake. Survival to recruitment to the fishery would depend on other factors.

This strike analysis should be considered exploratory, not definitive. The angular arguments for the water velocity vector were not estimated; therefore, the resulting implicit assumption that the velocity of fish passing through the plane of the vane leading edge rotation equaled the expected mean water velocity entering the turbine runner has potentially resulted in underestimation of strike probability. In addition, experience with a prediction of injuries and mortalities resulting from blade leading edge strike has shown

${ }^{1}$ From a draft report to the US Army Corps of Engineers - Portland District by Carlson, T.J., C.S. Abernethy, R.A. Moursund, and H. Kos. Pilot Study of the Effects of Simulated Turbine Passage Pressure on Juvenile Chinook Salmon Acclimated with Access to Air at Absolute Pressures Greater than Atmospheric, in review March 2005. 
that not all strikes result in injury and that the rates of injury and mortality following strike are a function of fish size and other physiological factors (Cada et al. 1997). Finally, the results are only applicable to the seven-vane pump runners that remain at the Pump-Generating Plant. The probability of strike, at least as modeled here, would increase in proportion to the number of additional vanes in the new pump runners. 


\subsection{Conclusions and Recommendations}

\subsection{Conclusions}

Based on our field study and analysis, the following conclusions can be made:

- The conditions for fish passage in pump flow through pump unit \#5 appear good with the exception of passage through the pump runner.

- Physoclistous and physostomous fish acclimated to pressures no greater than 1.4 times the lowest point in pressure through the turbine runner (on the order of $15 \mathrm{psi}$ ) should have a low level of risk of pressure-related injury during passage through the runner.

- Estimates of probability of strike indicate that the majority of kokanee, particularly newly released juveniles, entrained in pump flow should pass through the pump runner without being struck, although the risk of strike increases significantly over the size range of kokanee potentially at risk of entrainment.

- Overall it is probable that the majority of kokanee entrained in pump flow for the original sevenvane pump runners survive entry to the feeder canal.

\subsection{Recommendations}

Based on the conclusions above, we make the following recommendations:

- Obtain passage condition information using the Sensor Fish Device for the nine-vane pump-only and pump-generator units at the Pump-Generating Plant.

- $\quad$ Perform studies to estimate the proportion of kokanee hatchery production entrained in pump flow and the survival into Banks Lake for those fish entrained in pump flow. 
Characterization of Pump Flow at the Grand Coulee Dam Pumping Station for Fish Passage, 2004 


\subsection{References}

Abernethy, C.S., B.G Amidan, and G.F. Cada. 2001. Laboratory Studies of the Effects of Pressure and Dissolved Gas Supersaturation on Turbine-Passed Fish. PNNL-13470, Pacific Northwest National Laboratory, Richland, WA.

Cada, G.F., C.C. Coutant, and R.R. Whitney. 1997. Development of Biological Criteria for the Design of Advanced Hydropower Turbines. Environmental Sciences Division, Oak Ridge National Laboratory, Oak Ridge, Tennessee.

Carlson, T.J. and J.P. Duncan. 2003. Evolution of the Sensor Fish Device for Measuring Physical Conditions in Severe Hydraulic Environments. DOE/ID-11079. Prepared for US DOE, Idaho Operations Office, Pacific Northwest National Laboratory, Richland, Washington.

Carlson, T.J. and J.P. Duncan. 2004. Characterization of the McNary Dam Turbine Fish Passage Environment, April 2002. PNWD-3310, Prepared for the U.S. Army Corps of Engineers, Walla Walla District, by Pacific Northwest National Laboratory, Richland, Washington.

Franke, G.F., D.R. Webb, R.K.Fisher, Jr., D. Mathur, P.N. Hopping, P.A. March, M.R. Headrick, I.T. Laczo, Y.Ventikos, F. Sotiropoulos. 1997. Development of Environmentally Advanced Hydropower Turbine System Design Concepts. INEEL/EXT-97-00639. U.S. Department of Energy, DOE Idaho Operations Office, Idaho Falls, Idaho.

Hubbard C. 1995. "Hydroelectric Power Generation.” <http://users.owt.com/chubbard/gcdam/html/hydro.html> (25 November 2003).

Johnson RL, MA Simmons, CA McKinstry, CS Simmons, CB Cook, RS Brown, DK Tano, SL Thorsten, DM Faber, R LeCaire, and S Francis. 2005. Strobe Light Deterrent Efficacy Test and Fish Behavior Determination at Grand Coulee Dam Third Powerplant Forebay. PNNL-15007, Pacific Northwest National Laboratory, Richland, Washington.

Ploskey, G.R. and T.J. Carlson. 2004. Comparison of Blade-Strike Modeling Results with Empirical Data. PNNL-14603, prepared for the U.S. Department of Energy Advanced Hydropower Turbine System Program by the Pacific Northwest National Laboratory, Richland, Washington.

McLellan, H.J., A.T.Scholz, and J.G. McLellan. 2004. Open Water Release Strategies for Kokanee in Lake Roosevelt, 2003. Report submitted to the Spokane Tribe of Indians, Wellpinit, Washington.

Turnpenny, A.W.H. 1998. "Mechanisms of Fish Damage in Low-Head Turbines: An Experimental Appraisal.” In Fish Migration and Fish Bypasses, eds. M. Jungwirth, S. Schmutz, and S. Weiss, pp. 300-314. Fishing News Books, Blackwell Publishing, Oxford, United Kingdom.

Turnpenny, A.W.H., D.M. Davis, J.M. Fleming, and J.K. Davies. 1992. Experimental Studies Relating to the Passage of Fish and Shrimps through Tidal Power Turbines. National Power PLC, Fawley, Hampshire, United Kingdom.

Turnpenny, A.W.H., S. Clough, K.P. Hanson, R. Ramsay, and D. McEwan. 2000. Risk Assessment for Fish Passage through Small, Low-Head Turbines. Energy Technical Support Unit, Harwell, United Kingdom. 
Characterization of Pump Flow at the Grand Coulee Dam Pumping Station for Fish Passage, 2004 